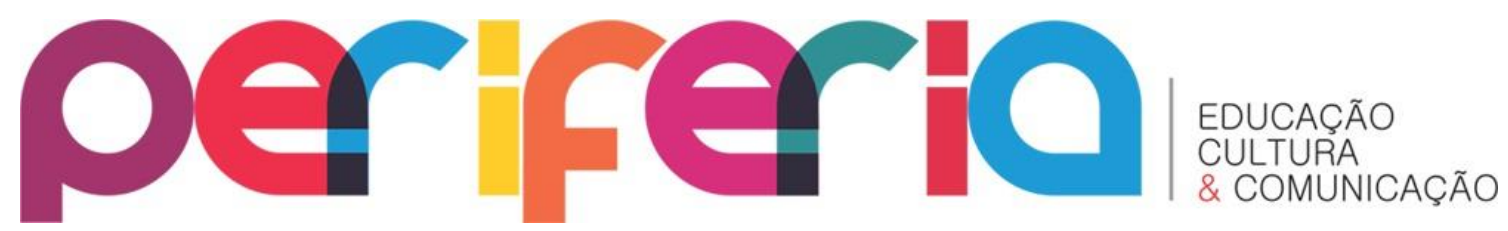

\title{
LIMITES E DESAFIOS DA RELAÇÃO DA ESCOLA MUNICIPAL DR. JOSÉ GARCIA NETO COM A COMUNIDADE RURAL DO ASSENTAMENTO PALMEIRA NO MUNICÍPIO DE NIOAQUE - MS
}

\author{
Rodrigo Simão Camacho ${ }^{1}$ \\ Kamila de Aguiar Gomes Soares ${ }^{2}$ \\ Cristina Oliveira Ferreira ${ }^{3}$
}

Resumo: 0 artigo buscou destacar a importância da permanência da Escola Municipal Dr. José Garcia Neto no assentamento Palmeira, município de Nioaque - MS, além de identificar o tipo de relação que a escola estabelece com a comunidade, relatando os avanços e desafios para a sua ocorrência. A relação escola-comunidade não é feita de uma maneira rápida e direta, exige todo um processo de intervenções planejadas pela escola para que ela aconteça. No processo de desenvolvimento do artigo, primeiramente, questionamos as possibilidades e viabilidades dos projetos a serem disponibilizados pela escola, em seguida, à disposição da escola e da comunidade em realizá-los na prática e, através disso, como estão criando e fortalecendo os vínculos. A metodologia do trabalho se deu por meio da pesquisa-participante e, principalmente, das entrevistas com os estudantes, os pais dos estudantes e o diretor da escola. Os resultados demonstram que a aproximação, escola e comunidade, trazem muitos benefícios tanto para a escola, quanto para a comunidade. Consideramos que temos a possibilidade concreta de termos uma escola de qualidade no/do campo e, inclusive, com o apoio da comunidade.

Palavras-Chaves: Escola do Campo, Comunidade Rural, Relações Sociais, Assentamento.

\footnotetext{
1 Doutor em Geografia pelo Programa de Pós-Graduação em Geografia da Universidade Estadual Paulista (Unesp/Presidente Prudente). Docente do curso de Licenciatura em Educação do Campo (LEDUC) e do Programa de Pós-Graduação em Educação e Territorialidade na Faculdade Intercultural Indígena (FAIND) - Universidade Federal da Grande Dourados (UFGD). Docente nos Programas de Pós-Graduação em Geografia na FCH-UFGD e na Universidade Federal de Mato Grosso do Sul (UFMS/Três Lagoas). ORCID: https://orcid.org/0000-0002-3826-6248 . E-mail: rogeo@ymail.com

2 Graduada em Licenciatura em Educação do Campo (LEDUC) na Faculdade Intercultural Indígena (FAIND) - Universidade Federal da Grande Dourados (UFGD). Professora na Educação Básica do Campo. ORCID: https://orcid.org/0000-0002-9939-6943. E-mail: kamy_201214@hotmail.com

${ }^{3}$ Graduada em Geografia pela Faculdade de Ponta Porã (FAP) e em Pedagogia pela UNIGRAN. Especialização em Gênero e Interculturalidade pela UGFD e Especialização em Educação no Campo pela UFMS. Cursando Mestrado em Geografia pela UFGD. Professora de Geografia e Eixos Temáticos na Educação Básica em escolas do campo. ORCID: https: / /orcid.org/0000-0002-62090000. E-mail: crismuller.oliveira@gmail.com.
} 


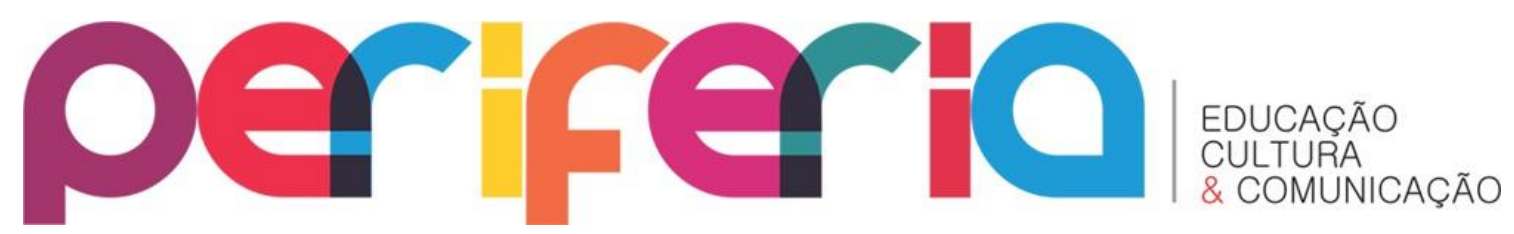

\section{LIMITS AND CHALLENGES OF THE RELATIONSHIP OF THE MUNICIPAL SCHOOL DR. JOSÉ GARCIA NETO WITH THE RURAL COMMUNITY OF THE PALMEIRA LAND REFORM SETTLEMENT IN THE MUNICIPALITY OF NIOAQUE - MS}

Abstract: The article sought to highlight the importance of staying at the Municipal School Dr. José Garcia Neto in the Palmeira settlement, municipality of Nioaque - MS, in addition to identifying the type of relationship that the school establishes with the community, reporting the progress and challenges for its occurrence. The school-community relationship is not done quickly and directly, it requires a whole process of interventions planned by the school for it to happen. In the process of developing the article, we first question the possibilities and feasibility of the projects to be made available by the school, then, at the disposal of the school and the community to carry them out in practice and, through this, how they are creating and strengthening bonds. The methodology of the work took place through participant research and, mainly, through interviews with students, students' parents and the school principal. The results demonstrate that the approach, school and community, bring many benefits to both the school and the community. We believe that we have the concrete possibility of having a quality school in the countryside and, even, with the support of the community.

Keywords: Countryside School, Rural Community, Social Relations, Settlement.

\section{LÍMITES Y DESAFÍOS DE LA RELACIÓN DE LA ESCUELA MUNICIPAL DR. JOSÉ GARCIA NETO CON LA COMUNIDAD RURAL DE LA REFORMA AGRARIA DEL PALMEIRA EN EL MUNICIPIO DE NIOAQUE - MS}

Resumen: El artículo buscó resaltar la importancia de hospedarse en la Escuela Municipal Dr. José García Neto en el asentamiento Palmeira, municipio de Nioaque - MS, además de identificar el tipo de relación que la escuela establece con la comunidad, reportando los avances y desafíos para su ocurrencia. La relación escuela-comunidad no se hace rápida y directamente, requiere de todo un proceso de intervenciones planificadas por la escuela para que suceda. En el proceso de elaboración del artículo, primero cuestionamos las posibilidades y viabilidad de los proyectos a ser puestos a disposición por la escuela, luego, 


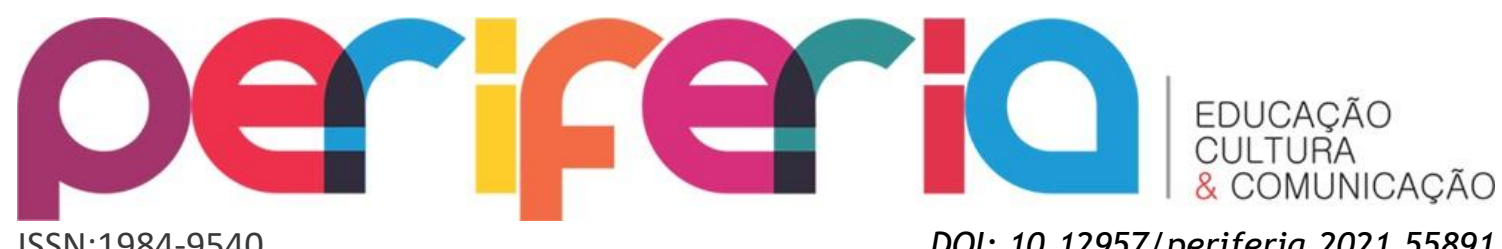

ISSN:1984-9540

DOI: 10.12957/periferia.2021.55891

a disposición de la escuela y la comunidad para llevarlos a cabo en la práctica y, a través de esto, cómo se están creando y fortaleciendo vínculos. La metodología del trabajo se llevó a cabo a través de la investigación participante $\mathrm{y}$, principalmente, a través de entrevistas con los estudiantes, los padres de los estudiantes y el director de la escuela. Los resultados demuestran que el enfoque, la escuela y la comunidad, aportan muchos beneficios tanto a la escuela como a la comunidad. Creemos que tenemos la posibilidad concreta de tener una escuela de calidad en el campo e, incluso, con el apoyo de la comunidad.

Palabras clave: Escuela de Campo, Comunitario Rural, Relaciones Sociales, Asentamiento

\section{Introdução}

Este artigo teve por objetivo identificar à Importância da Escola Dr. José Garcia Neto para a Comunidade Rural do Assentamento Palmeira, que está localizada no município de Nioaque, que fica a $186 \mathrm{~km}$ da capital, Campo Grande, estado de Mato Grosso do Sul,

Identificamos quais são as relações que a escola tem com a comunidade do assentamento. Averiguamos como é estabelecido essa aproximação, quais são as ações utilizadas e como se dá a interação da participação dos membros da escola e da comunidade em assembleias e reuniões de conselhos. Interpretamos de que forma esta interação pode beneficiar ambas as partes.

0 tema escolhido deve-se ao reconhecimento dos vários problemas que as escolas do campo vêm sofrendo ao longo dos anos, seja pela falta de ofertas de professores habilitados, políticas públicas específicas e o mais grave de todos os problemas, o fechamento dessas escolas. A importância de se refletir sobre a relação entre comunidade e escola é de que se fortaleça os seus vínculos e, assim, a escola seja o produto concreto das relações sociais estabelecidas na comunidade camponesa onde se encontra inserida.

$\mathrm{Na}$ verdade, a Educação do Campo é o resultado da construção de um "Novo Campo" que apesar de se encontrar ainda excluído de políticas públicas que contemplem seus 


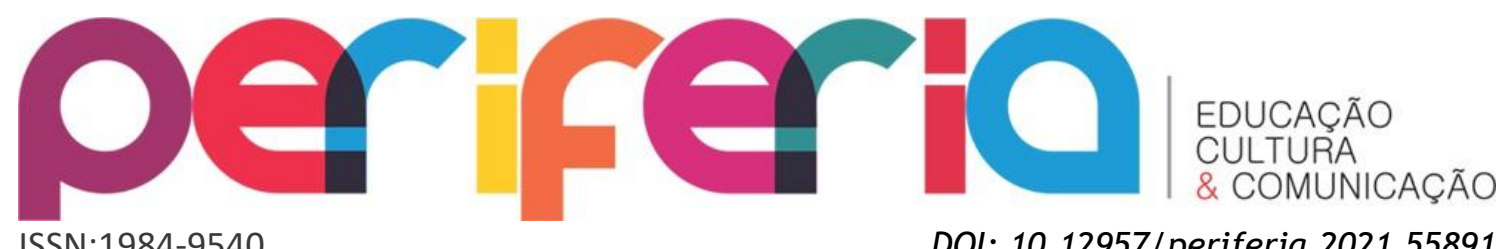

DOI: $10.12957 /$ periferia.2021.55891

moradores, está em constante movimento e esse movimento traz em sua trajetória a consciência política de seus habitantes. Continuam, dessa maneira, produzindo cultura e necessitando de uma escola que reflita essa nova dinâmica social produzida no campo brasileiro. (CAMACHO, 2011, p. 101).

A escola não se faz escola sem professores, alunos e gestores, mas também, necessita da interação da mesma com a comunidade. Fortalecendo os seus vínculos para que possamos construir uma escola que tenha a garantia e a proteção da comunidade, favorecendo-a para que se em algum dia essa escola venha a ser alvo de possível fechamento, ela tenha meios de defesa por parte da comunidade, dificultando, ou mesmo, impedindo o seu fechamento.

É importante mencionar a parte institucional que envolve o Projeto Político Pedagógico (PPP) voltado à realidade dos estudantes do campo, e também a responsabilidade do Estado para financiamento e execução de mais políticas públicas que favoreçam os povos do campo. Com esses aspectos positivos, acreditamos que podemos construir cada vez mais uma Educação do Campo de qualidade.

O problema a ser colocado em questão nos ajuda a refletir também sobre o abandono do Estado para com as escolas rurais. Se analisarmos melhor, podemos considerar que é de suma importância e é de extrema necessidade que se tenha em uma Escola do Campo: uma biblioteca com diversos livros, não só didáticos, como também literários, sala de informática com internet, para ser utilizada em pesquisas e atividades dos docentes por meio dos computadores, sala de recursos, áreas de lazer e quadras de esportes, entre vários outros meios. Além disso, segundo a LDB Lei de Diretrizes e Bases da Educação Nacional (LDB):

Art. 28: Na oferta de educação básica para a população rural, os sistemas de ensino promoverão as adaptações necessárias às suas adequações às peculiaridades da vida rural e de cada região, especialmente: I - conteúdos curriculares e metodologias apropriadas às reais necessidades e interesses da zona rural; II - organização escolar própria, incluindo adequação do calendário escolar, às fases do ciclo agrícola e às condições climáticas; III - adequação a natureza do trabalho rural. 


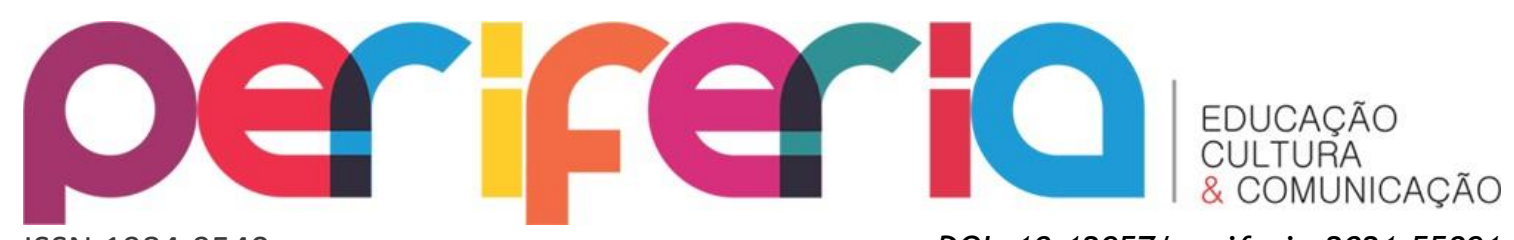

ISSN:1984-9540

DOI: $10.12957 /$ periferia.2021.55891

Assim, é necessário que todas as escolas que se localizam no campo recebam o investimento necessário do Estado e que atendam as especificidades que a comunidade e a escola precisam, relacionando a realidade vivida no campo. Atendidas estas condições seria um incentivo para os alunos estudarem e continuarem em sua comunidade. 0 desenvolvimento ensino-aprendizagem dos nossos estudantes seria bem mais avançado e o docente teria várias formas de mediar este processo com mais facilidade usando esses recursos oferecidos.

Todos estes desafios devem ser enfrentados coletivamente entre escola e a comunidade, para que a construção da escola, em si, possa ser estabelecida, trazendo qualidades de uma educação valorizada e respeitada, tanto pelo Estado quanto pela comunidade, buscando sempre alternativas de melhorias para uma vida camponesa sem a perda de sua cultura e o seu modo de viver.

Para construção do artigo, dividimos o texto da seguinte maneira. Primeiramente, fizemos uma reflexão teórica acerca da Educação do Campo e a importância das escolas do campo para a sua efetivação. Em seguida, construímos uma breve trajetória da gênese, desenvolvimento e a atualidade da Escola Municipal Dr. José Garcia Neto, por meio de fotografias, observações e relatos coletados em entrevistas dos sujeitos participantes do processo. Enfim, por último, mostramos os resultados da pesquisa em que procuramos ouvir os sujeitos da escola e da comunidade, a fim de explicar como as relações entre ambas estão sendo construídas e efetivadas, seus limites e desafios, mas também, buscamos ter uma atitude propositiva na pesquisa, elencando alternativas de ações que podem ser organizadas pela escola para aprofundar os vínculos entre escola-comunidade.

\section{Metodologia}

Durante o percurso metodológico fizemos uma pesquisa quali/quantitativa. Nas entrevistas, a pesquisa envolveu perguntas abertas, ou seja, com resultados qualitativos, e outras perguntas fechadas (quantitativas) 


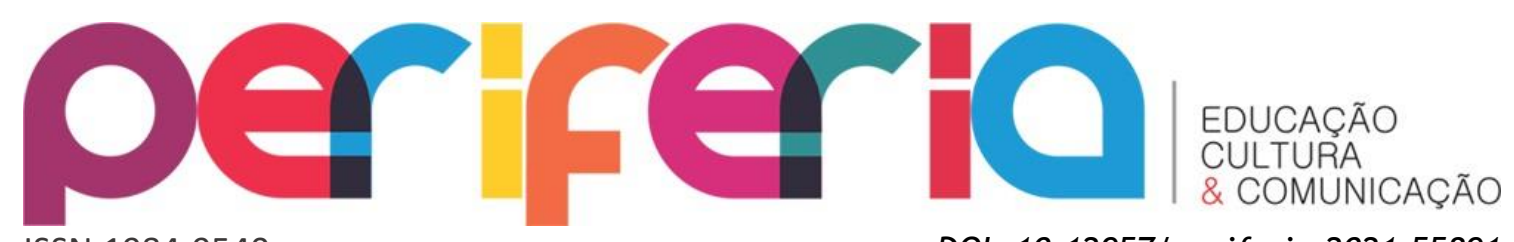

ISSN:1984-9540

DOI: $10.12957 /$ periferia.2021.55891

para abordar dados estatísticos. Ambas tiveram o mesmo objetivo de interpretar as relações que envolvem a comunidade e a escola.

O primeiro passo foi a pesquisa-bibliográfica a fim de desenvolver a reflexão teórica por meio de artigos científicos, livros, monografias, dissertações e teses de autores que discutem os conhecimentos específicos para com a nossa temática discutida, como Educação do Campo, Movimentos Sociais, Escolas do Campo, Reforma Agrária etc.

No segundo momento, fizemos a coleta de dados por meio de entrevistas com roteiros semiestruturados que buscaram analisar o contato da escola $\mathrm{Dr}$. José Garcia Neto com a comunidade rural (Assentamento Palmeira no Município de Nioaque - MS).

Primeiramente, tivemos como público-alvo da entrevista o diretor, ao qual fizemos quinze perguntas, por meio de um roteiro semiestruturado. Para os estudantes da escola (cinco estudantes de $5^{\circ}$ ao $9^{\circ}$ ano) usamos um roteiro contendo cinco perguntas iguais para todos, bem como, para os pais (cinco pais), que também fizemos a entrevista com cada um contendo cinco perguntas.

Também, fizemos a pesquisa-documental, no caso, a análise do projeto político-pedagógico, foi outra fonte de dados para a pesquisa. Outra metodologia usada foi a observação-participante, tendo em vista que fizemos estágio na escola e moramos no assentamento pesquisado, por isso, pudemos fazer um relatório do que foi observado e expresso em conversas informais durante o período de interação que tivemos dentro da escola e da comunidade.

Apresentamos os resultados da pesquisa por meio de gráficos, tabelas, fotografias e transcrição das narrativas dos sujeitos pesquisados em que foi possível refletir de maneira crítica e propositiva sobre os avanços e limites da interação da escola com a comunidade, observando ambos os espaços de relações socioterritoriais. 


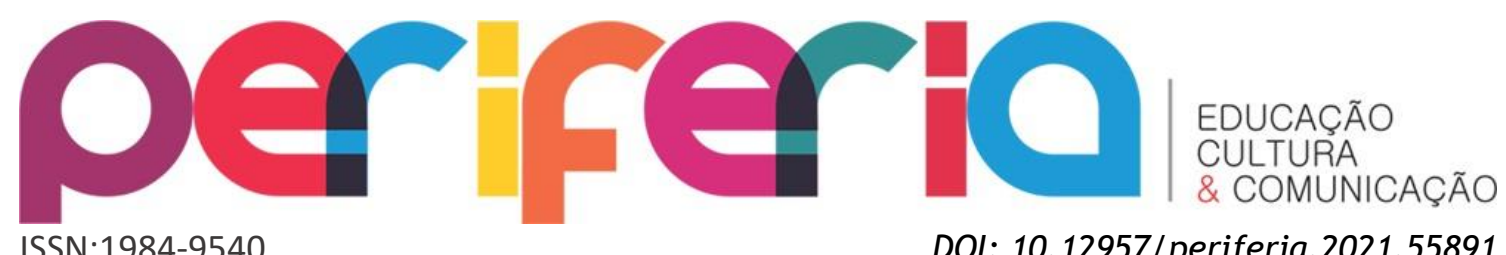

\section{A Educação do Campo: Uma Reflexão acerca das Escolas do Campo}

Para discutir Educação do Campo, estamos partindo da perspectiva de que para os camponeses-assentados, as escolas do campo cumprem a função social, para além da educação formal, servido de espaços de socialização do assentamento.

As poucas escolas existentes no campo fazem uma grande diferença para a comunidade onde se localiza, pois, tendo uma unidade escolar dentro do assentamento, podemos dizer que tudo se torna bem mais acessível, tanto para os professores e alunos, quanto para os demais moradores. Assim, tanto estudantes quanto docentes, que residem no campo, não precisam sair para estudarem ou lecionarem na cidade, e os pais podem acompanhar ativamente as atividades da escola.

A escola da Educação do Campo nasce como uma das dimensões de luta pela conquista de um modo de produção de vida. Nesse sentido, se articula com um conjunto de princípios, conceitos e práticas em construção, no conjunto das lutas empreendidas pelos trabalhadores do campo. Sendo assim, a escola também se insere como um território a ser ocupado (ROCHA; MARTINS, 2012, p. 3).

É fundamental que se tenha uma escola inserida no campo, e mais ainda que ela seja uma escola do/para o campo, ou seja, uma escola que priorize, em primeiro lugar, a identidade dos povos do campo, e não seja apenas "mais uma escola inserida em um determinado assentamento". Mas sim, uma escola que visa ensinar aos educandos uma educação libertadora, que valorize essa identidade provinda dos povos camponeses e, assim, possa construir conhecimentos condizentes com a realidade de onde se encontram inseridos (CAMACHO, 2011).

Escola do Campo e Educação do Campo são dois conceitos diferentes, mas não antagônicos, pois ambos não funcionam separados. Para conceituarmos uma Escola do Campo, primeiramente, ela deve estar inserida dentro da comunidade, e segundo, suas metodologias de ensino-aprendizagem, necessariamente, precisam estar voltadas, de fato, para a realidade onde 


\section{0 ar fer}

vivem, mesmo que esta realidade esteja conectada com o mundo globalizado e tecnológico, que possibilita a abertura para novos conhecimentos. Embora tenhamos essa concepção de Escola do Campo ideal, sabemos que para atingir este objetivo, ela precisa ser modificada dia após dia sem perder a essência da realidade (econômica, política, sociocultural, territorial) camponesa (VIEIRA; CAMACHO, 2020).

De fato, a educação se mostra muito importante no meio em que vivemos, e para nós moradores do campo, a educação é fundamental para que nossas conquistas sejam efetivadas em sua totalidade. Embora tenhamos muitos desafios pela frente para constituirmos uma Escola do Campo na perspectiva, de fato, da Educação do Campo, não deixamos de lutar pela educação básica do campo. Deste modo, a "Educação do Campo surge como uma forte característica de luta pela Reforma Agrária, por um projeto de Desenvolvimento do Campo e do Brasil e pela luta da garantia dos direitos dos trabalhadores (TAFFAREL, 2010, p.57).

Sendo assim, observamos que a conquista de nossas terras não se dá somente pelo fato de se ter um lote onde morar, mas podemos destacar que essas conquistas devem abranger as múltiplas dimensões do território conquistado, como: acesso as políticas públicas, acesso à saúde, preservação ambiental e, inclusive, acesso à escola (FERNANDES, 2006).

Segundo Arroyo e Fernandes (1999, p.18): as políticas públicas, respeitando a constituição federal, coloca a educação no terreno dos grandes valores da vida e da formação humana. Assim, analisamos que, em meio a todas estas conquistas que se identifica como direito de todos, dentre essas a educação, uma das demandas que mais necessitamos dentro de um assentamento e, que se torna de extrema importância, são escolas que estejam acessíveis para crianças e adolescentes. Pensando não só na questão do acesso, mas sim como um todo, estrutura, espaço, qualidade de ensino, projetos pedagógicos, habilitação de professores, conteúdos programáticos, comunicação no meio social e entre várias outras características que compõe o corpo escolar. 


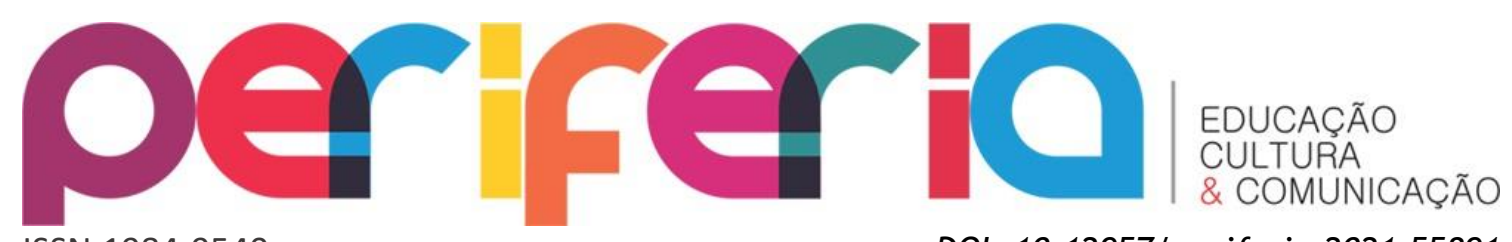

ISSN:1984-9540

DOI: $10.12957 /$ periferia.2021.55891

A Escola do Campo deve estar condizente com a perspectiva de Educação do Campo proposta por Caldart (2004, p.2): “Nossa proposta é pensar a Educação do Campo como processo de construção de um projeto de educação dos trabalhadores e das trabalhadoras do campo, gestado desde o ponto de vista dos camponeses e da trajetória de luta de suas organizações". Portanto, é evidente que o trabalho em coletividade é primordial para uma Educação do Campo de qualidade, ou seja, trabalhando junto escola e comunidade.

Consideramos que a permanência de uma escola dentro da comunidade faz toda a diferença no processo de ensino-aprendizagem, porém, ela só funcionará se tiver a permanência dos sujeitos no campo, ou seja, um número de educandos suficientes para estudarem, caso contrário, além da não construção de mais escolas do campo, também, abre possibilidades para o fechamento das existentes. Desta forma, entendemos a importância que tem a resistência dos camponeses na terra, e a articulação desta resistência com a escola do assentamento. Isto quer dizer que o processo de êxodo rural acarretará, também, a diminuição do número de estudantes que frequentam a escola, ou seja, a priori, podemos afirmar que sem estudantes no campo, não existe escolas do campo, por isso, resistir no campo contra o avanço do capital é necessidade fundamental para que a Educação do Campo continue se reproduzindo nas escolas do campo (CAMACHO, 2019).

Quando ocorre a desterritorialização dos estudantes-camponeses, o Estado faz alterações que vão desde a formação das salas multisseriadas até o maior impacto para a Educação do Campo, qual seja, o fechamento de escolas.

O fechamento de escolas em áreas rurais do Brasil não para de crescer. De acordo com um levantamento da Universidade Federal de São Carlos (UFSCar), de 2002 até o primeiro semestre de 2017, cerca de 30 mil escolas rurais no país deixaram de funcionar. (DEISTER, 2018, p.01).

Quando falta escolas dentro dos assentamentos, muitas crianças e jovens estão sujeitos a levantarem muito cedo para chegaram até a escola, pois o ônibus escolar faz uma rota inteira dentro do assentamento, e depois que todos os estudantes entram no ônibus, seguem em destino até as escolas urbanas. 


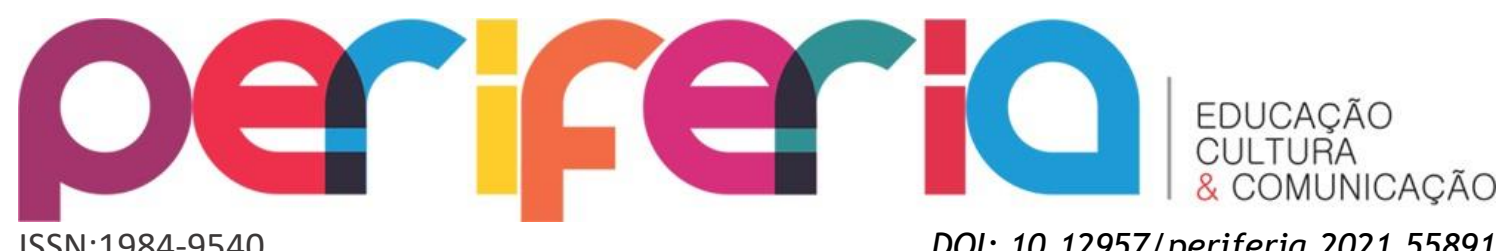

Este fato, cria uma grande defasagem no aprendizado da criança e da juventude camponesa, pois além do cansaço, o sono prejudica o estudante em suas aulas, fazendo com que não tenha um bom desempenho, além, de afetar na parte da saúde, tanto física como também, psicológica (MACIEL, 2020).

Corroborando nesse sentido, Munarin (2006, p.24) aponta que "em consequência, crianças são submetidas a longas horas diárias de transporte cansativo e inadequado, ao mesmo tempo em que passam a receber escolarização totalmente descontextualizada".

Diante desse cenário, a discussão da Educação do Campo deve ser pensada a partir dos avanços que tivemos, mas também nos retrocessos, pois o fechamento de escolas do campo nos assentamentos afeta todos os sujeitos, professores, gestores e educandos do campo que tem o direito de ter uma educação humanizadora/emancipatória e que permita estabelecer a relação do diálogo de saberes técnico-científicos e populares-camponeses.

\section{Um esboço do histórico da Escola Municipal Dr. José Garcia Neto}

Ao analisar a trajetória da escola, vemos que, primeiramente, a sua fundação se deu no Assentamento Colônia Nova em 1972, mas só em 1973 é que a escola recebeu o nome de “Escola Municipal Dr. José Garcia Netto". O assentamento Colônia Nova foi o primeiro assentamento da região fundado em 1972 e foi escolhido para a construção da primeira escola rural, na qual foi estruturada apenas em uma pequena sala de aula feita de madeira.

A escola "iniciou-se com uma sala de pau-a-pique em sistema multisseriadas" (GARCIA, 2014, p. 29) (figura 1). Nessa época, para manter a escola foi preciso fazer um trabalho solidário, não havia um coordenador específico para a escola, e nem ao menos um diretor. A escola era direcionada pelo próprio professor, ou seja, ele era quem administrava a escola por si próprio.

Para atender todas as crianças que se encontravam fora da escola, por falta de estradas e de transportes escolares, o prefeito aumentava as aberturas de salas de aulas como extensões, aumentando assim a problemática de atendimento 


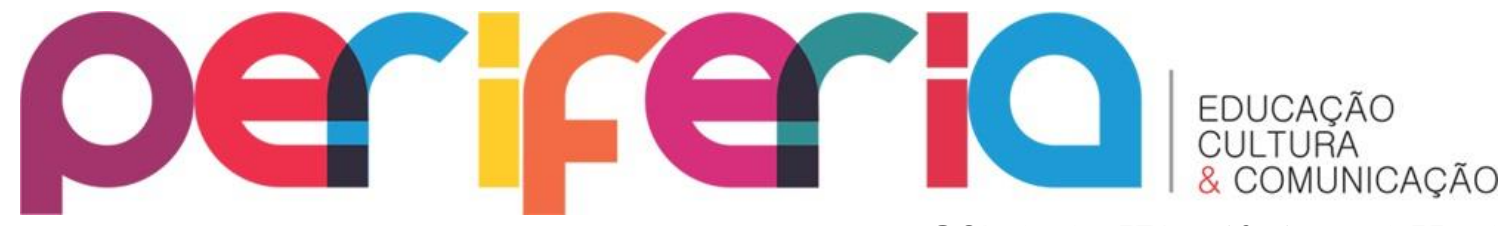

ISSN:1984-9540

DOI: $10.12957 /$ periferia.2021.55891

da direção, da comunidade escolar e dos professores. Essas extensões funcionavam com sala multisseriada, onde um só professor atendia estudantes de várias séries, e esses professores em sua maioria eram leigos, sem formação especifica, pois os professores formados preferiam trabalhar na zona urbana. Com o passar dos anos, mudaram algumas situações, como a diminuição dos números de extensões, escolas que eram extensão se tornam polo, e a maioria das escolas tendo seu próprio diretor e coordenador pedagógico da própria comunidade. (SANTOS, 2018, p. 19).

Foi, então, através dessas modificações que a escola se tornou Polo, mesmo ela não tendo nenhuma extensão na época, ficando assim com o nome atualmente: “Escola Municipal Dr. José Garcia Netto - Polo”.

Figura 1 - Primeira escola rural de madeira, no assentamento Colônia Nova fundada em 1973, onde 1974 recebeu o nome de "Escola Municipal Dr. José Garcia Neto"

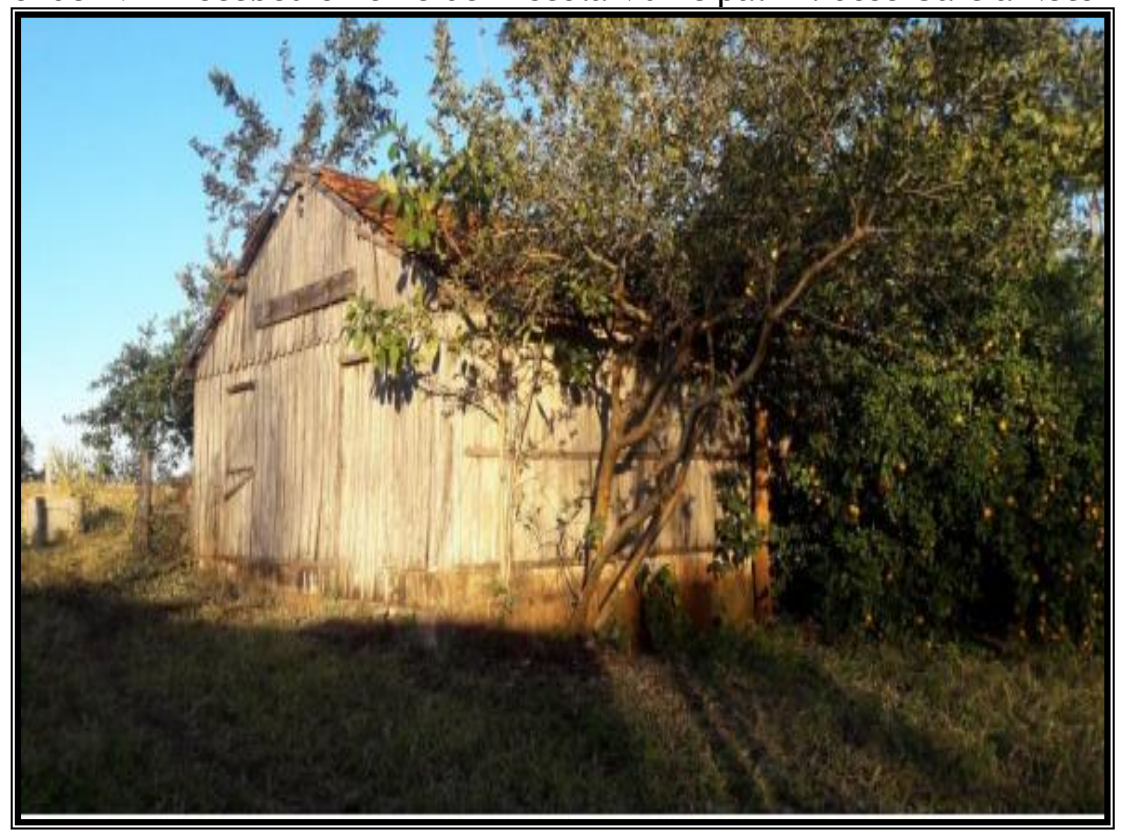

Fonte: SANTOS (2018, p. 18).

No ano de 1990, pelas péssimas condições que essa escola apresentava e pelo fato de ser muito antiga, construíram, então, um prédio novo (figura 2) no mesmo assentamento Colônia Nova, todavia com maior número de salas de aula, e com uma estrutura bem mais qualificada toda feita em alvenaria. “Foram construídos em 1990, na escola polo da Colônia Nova mais duas salas de aulas, dois banheiros e a cantina, todos de alvenaria, tendo assim aulas da $1^{\mathrm{a}} \mathrm{a}$ 


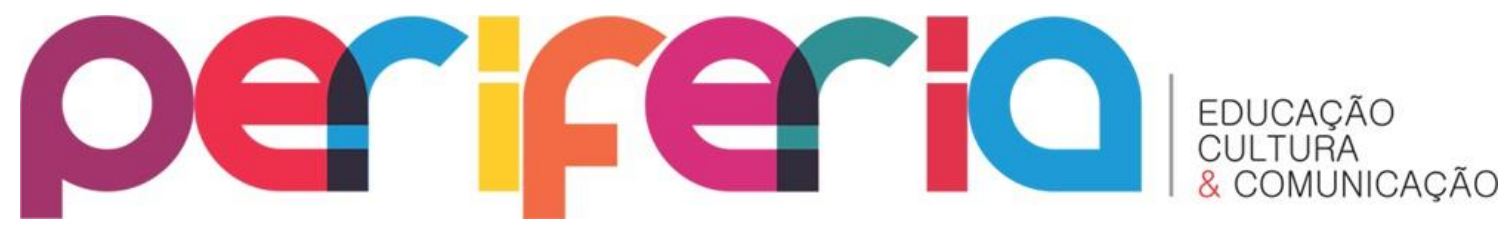

ISSN:1984-9540

DOI: 10.12957/periferia.2021.55891

$8^{\mathrm{a}}$ séries nos períodos matutino, vespertino e noturno" (SANTOS, 2018 p.19).

Nesse sentido,

Segundo Projeto Político Pedagógico Criada por intermédio da Lei Municipal $n^{\circ} 1.064 / 99$, passando para a atual denominação pela Lei Municipal $n^{\circ} 720 / 74$, a instituição é mantida pela Prefeitura Municipal de Nioaque, com o CNPJ 03.073.699/000108, localizada na Avenida General Klinger, $\mathrm{n}^{\circ} 405$, Centro, Nioaque Estado de Mato Grosso do Sul e administrada pela Secretaria Municipal de Educação com, nos termos da legislação em vigor e Regimento Escolar. (GARCIA, 2014, p.28).

Porém, a escola que foi construída no assentamento Colônia Nova fechou as portas em 2016, tendo como justificativa de que o motivo seria o custo alto de manutenção para poucos alunos matriculados. Em outras palavras: para economizar verbas públicas, o prefeito da época, senhor Gerson Garcia, mencionou a inviabilidade de manter a escola aberta diante do baixo número de estudantes nas salas em questão (SANTOS, 2018, p.21).

Figura 2 - Escola Municipal Dr. José Garcia Neto-Polo construída em alvenaria no assentamento Colônia Nova, que atualmente se encontra fechada.

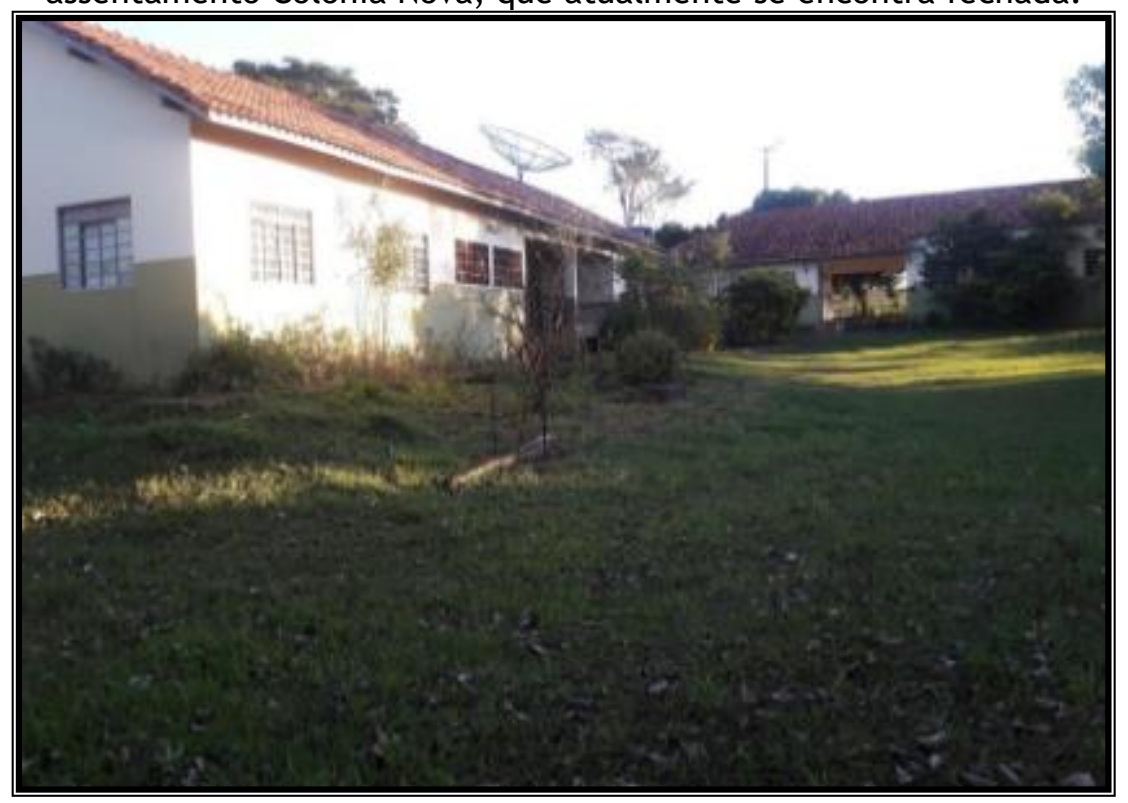

Fonte: SANTOS (2018, p.21)

Enquanto isso, no auge da conquista do assentamento Palmeira, um dos objetivos dos assentados era também de conquistar um espaço para uma escola rural. Assim, "quando constituído o Assentamento Palmeiras em dezembro de 


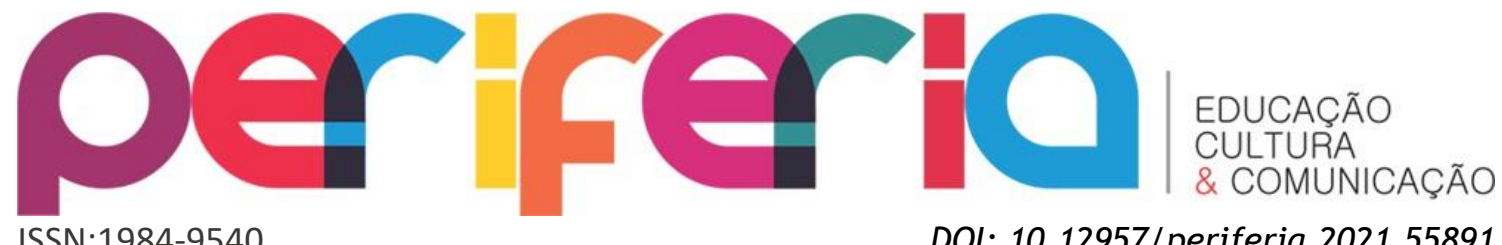

ISSN:1984-9540

DOI: $10.12957 /$ periferia.2021.55891 1997, começa o momento de transição. As famílias, em seguida, começam a construir seus barracos na área demarcada do lote”. (GARCIA, 2014, p. 32).

Segundo Garcia (2014), a escola localizada dentro do assentamento Palmeira, inicia suas atividades, primeiramente, como uma escola de extensão, por ser a sede principal no assentamento Colônia Nova. É importante destacar que "Como a certo modo a construção e efetivação da escola no Assentamento era resultado de luta da comunidade, os professores não deixavam de trabalhar com o contexto vivenciado naquele momento. (GARCIA, 2014, p. 32)”. Sendo assim, sua importância é ainda maior para a comunidade, porque nasce como uma conquista.

Figura 3 - Primeira escola construída de madeira no assentamento Palmeira, ainda quando era extensão da Escola Dr. José Garcia Netto - Polo.

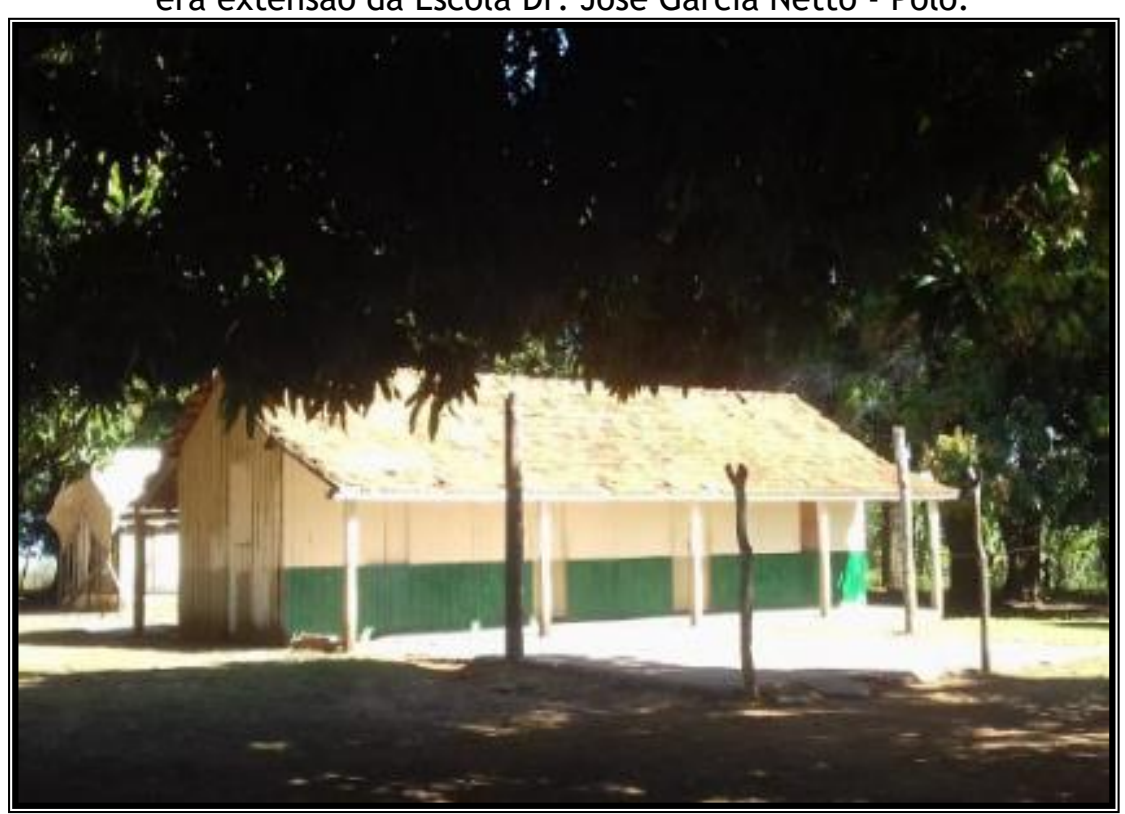

Fonte: SANTOS (2018, p. 22).

Ao observar a figura 3, nos deparamos com a primeira escola construída ainda de madeira, ou seja, pau-a-pique, no assentamento Palmeira, ao qual recebeu, por sua vez, o mesmo nome da escola que fica no assentamento Colônia Nova: “Escola Municipal Dr. José Garcia Netto-Polo”.

O que aconteceu com essa escola não foi muito diferente do ocorrido anterior, pois por ela ser antiga, tiveram então que tomar as devidas precauções, e também por questões de segurança dos estudantes e dos demais 


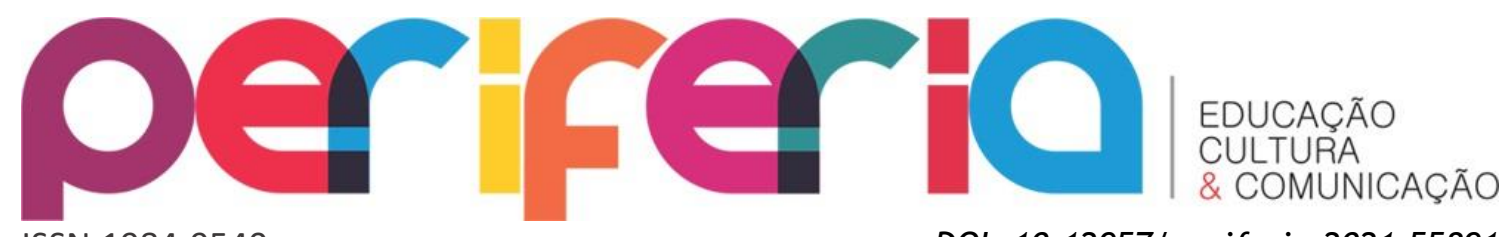

ISSN:1984-9540

DOI: $10.12957 /$ periferia.2021.55891 gestores da escola, ela teve que ser fechada para que pudesse ser feito o novo prédio, porém em melhores condições de estudar.

Contudo, a escola do assentamento Palmeira tem uma área bem extensa, por isso, é cabível de pensarmos em possíveis maneiras de se aproveitar esse espaço para articular diversos projetos que interaja com toda a comunidade. Assim, como nos mostra a figura 4 que tem como objetivo destacar os espaços que a escola tem ao entorno dela de uma forma mais geral, e assim analisarmos esses espaços com um olhar mais inovador e, ao mesmo tempo, crítico em poder utilizar essas áreas para fins pedagógicos.

O espaço escolar não é apenas um espaço constituído por salas de aula, há também um pátio, um refeitório, um jardim e, geralmente, há lugares ociosos, normalmente, localizados nos fundos da escola/colégio. Esses espaços quando olhados com atenção podem fazer a diferença na relação ensino aprendizagem e entre educandos-professores-comunidadeescola/colégio. (MATO GROSSO DO SUL, 2019, p. 26).

Figura 4 - Frente da Escola Municipal Dr. José Garcia Neto no assentamento Palmeira

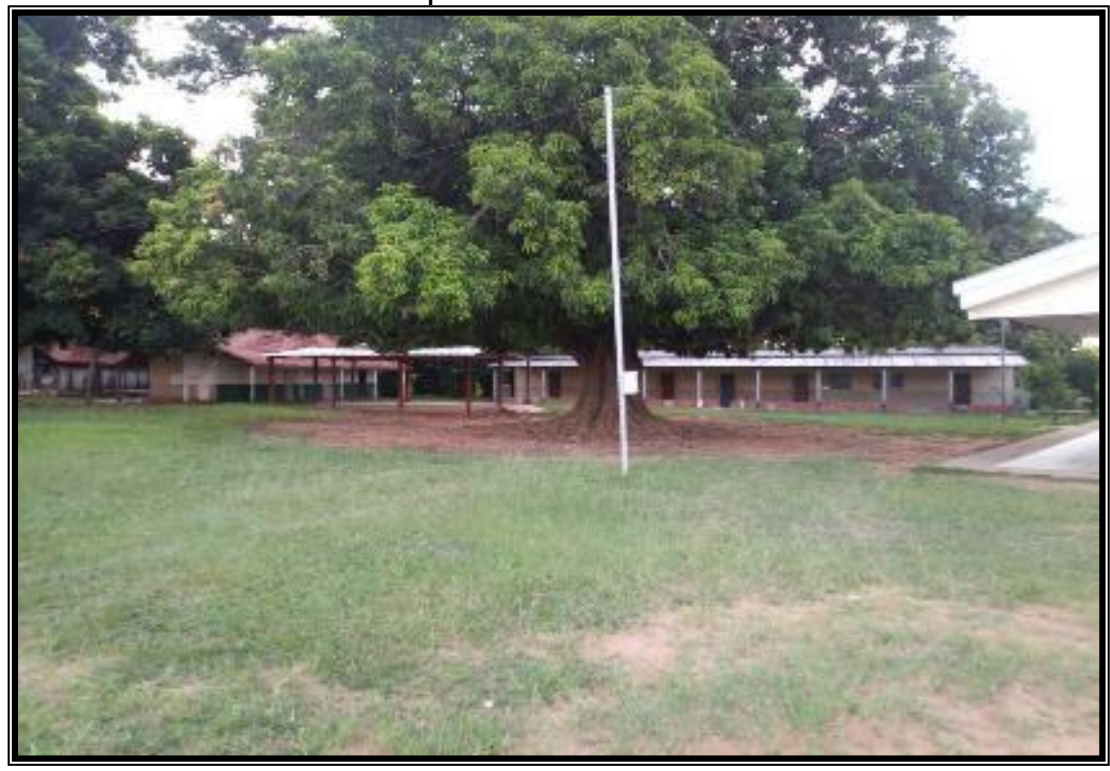

Fonte: AUTORES (2019).

\section{A Escola Municipal Dr. José Garcia Neto na atualidade}

Como foi dito, houve então o fechamento da escola de madeira, e logo depois teve que ser construído outro prédio novo (figura 5). De acordo com Santos (2018, p. 22): “Na escola atualmente, há 130 alunos matriculados, conta 


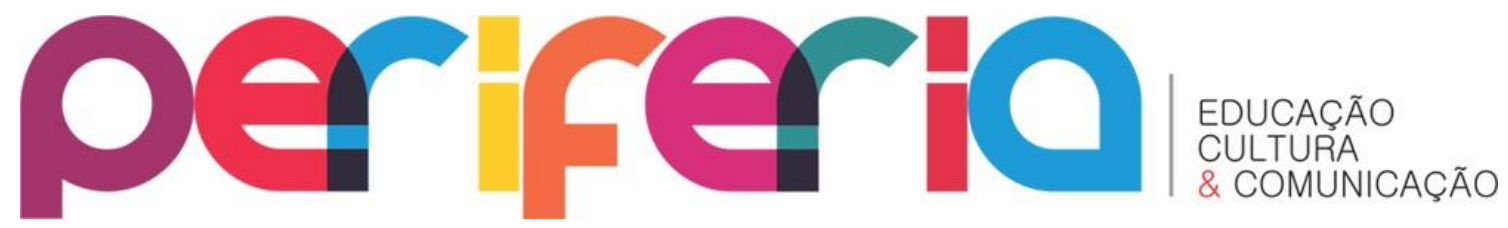

ISSN:1984-9540

DOI: $10.12957 /$ periferia.2021.55891 com um quadro de 20 funcionários, sendo - 1 diretor, 2 profissionais para serviços gerais, 1 cozinheira, 5 motoristas e 11 docentes”.

É necessário dizer que não é uma tarefa fácil manter a escola funcionando, esse esforço sempre será provindo de muita luta e força da escola e da comunidade, pois o apoio do Estado em relação ao orçamento é muito pouco, e assim como em todo assentamento, essa realidade não é diferente na escola Dr. José Garcia Neto.

Todavia, mesmo com todos os empecilhos por parte do Estado, ainda assim, não se torna um problema para que deixemos de pensar em uma escola de qualidade e de bem-estar para os povos do campo e que seja voltada para a realidade onde vivem.

Figura 5- Prédio novo da atual Escola Municipal Dr. José Garcia Neto no assentamento Palmeira

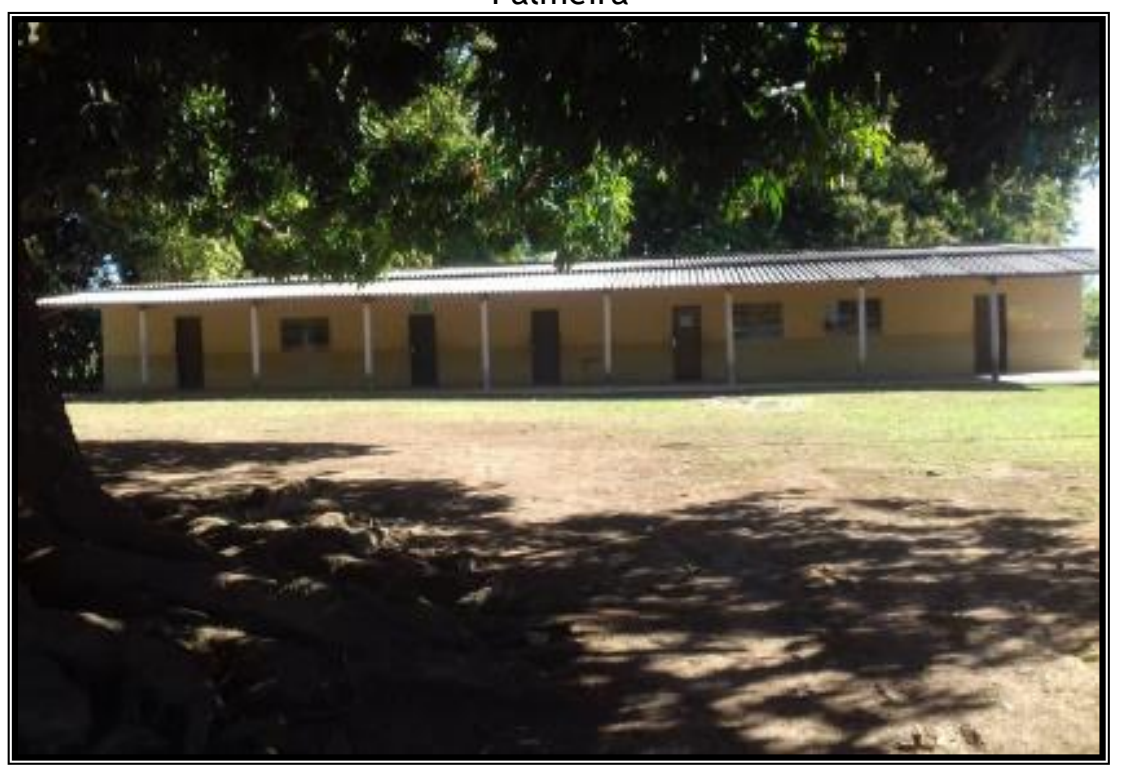

Fonte: SANTOS (2018, p.23).

Sistematizando os fatos, a permanência da escola Dr. José Garcia Neto no assentamento Palmeira é de extrema importância para os moradores do local. Com essa oportunidade, de ainda se ter essa escola dentro do assentamento, podemos pensar e articular formas dessa aproximação e de como desenvolver projetos dentro dela, atendendo as expectativas da comunidade, contando com sua participação. E, por fim, conseguir mobilizar os pais dos 


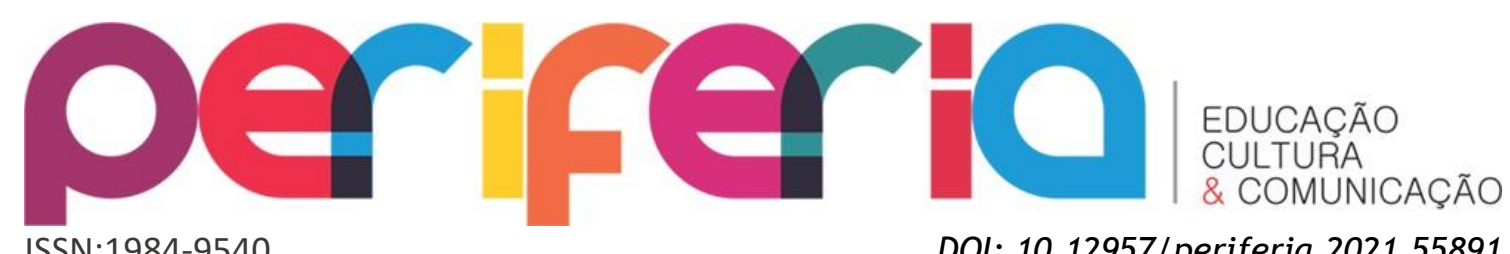

alunos, professores, gestores promovendo vários projetos que favoreçam todas as partes envolvidas.

Pensando nesta articulação escola-comunidade, fizemos algumas proposições de projetos que poderiam ser trabalhados na escola:

1- Uma horta comunitária de grande extensão, podendo trabalhar nesses aspectos com os educandos, de maneira interdisciplinar, as disciplinas ciências e Terra, Vida e Trabalho (TVT), apontando a origem da planta, o tempo determinado de ser plantada e estes podem conhecer os benefícios que cada uma proporciona para o ser humano. E a permanência dessa horta favorecerá também alimentos não só para a escola, mas como também para os moradores do assentamento.

2- Construção de uma cisterna, que possa ser canalizada e abastecer água tanto para escola como também para a comunidade e através disso ensinar aos estudantes a disciplina de geografia, ciências e TVT, trabalhando os conteúdos do ciclo da água, usos da água pela sociedade, formas de tratamento e os estados físicos da água.

3- Construção de uma área de lazer, em que se possa chamar a comunidade para fazer torneios nos finais de semana. E como a escola já possui um campo de futebol, é necessário que seja feita manutenção dessa área, organizar as linhas de limite do campo, arrumar redes novas para a prática do futebol e vôlei na disciplina de educação física, incentivando assim, com um espaço mais acolhedor, a prática de esportes.

4- Desenvolver projetos voltados para os cuidados com o meio ambiente como: o plantio de mais árvores em volta da escola, inclusive as nativas, que são muito importantes, e com isso chamar a comunidade para participar.

5- Outro projeto de meio ambiente é o aproveitamento do lixo reciclável para a confecção de artesanatos, em que, para além do trabalho em sala de aula, é possível instruir aos alunos a conversarem 


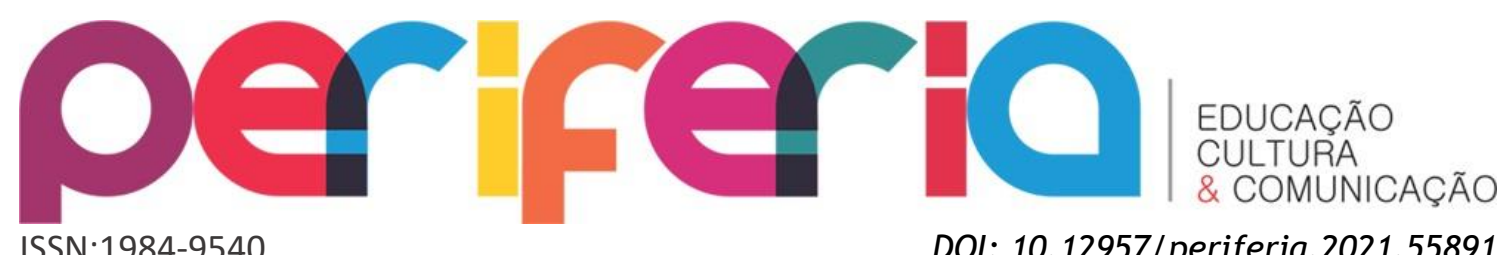

ISSN:1984-9540

DOI: $10.12957 /$ periferia.2021.55891

com a comunidade sobre como a reciclagem é importante e ajuda ao meio ambiente.

Formando, assim, uma aproximação entre a comunidade e a escola, por via dos projetos realizados, para que a comunidade possa estar conhecendo o que está sendo feito na escola, quais os planos futuros para as novas gerações e o que ainda deve ser melhorado. Trabalhando "comunidade e escola" juntas para uma construção social sem individualismos e segregação social. "Por isso, a Escola do Campo, pensada como parte de um projeto maior de educação da classe talhadora, se propõe a construir uma prática educativa que efetivamente fortaleça os camponeses para as lutas principais”. (MOLINA, 2011, p.328).

Um dos componentes específicos da realidade camponesa que é trabalhado na escola, é o Eixo-Temático Terra-Vida-Trabalho (TVT), ao qual, se encontra incluído no quadro curricular de disciplinas nas escolas do campo de Mato Grosso do Sul, e exige muito do esforço coletivo para que esta disciplina seja efetivamente trabalhada na escola.

No assentamento Palmeira, as aulas de TVT são dadas pelo professor de Educação Física, na qual, ele concilia as aulas de sua formação, com as aulas de TVT. Essas aulas são dadas uma vez na semana para cada turma. Um morador do assentamento nos relatou que essas aulas são feitas de forma bem simples, pois não têm outras alternativas a não ser o trabalho na horta e que, por conta da repetição dos conteúdos estudados ao longo dos anos, os educandos não se interessam pela disciplina.

Com a implantação da modalidade do campo, incluiu no currículo escolar o eixo Terra-Vida-trabalho, pois a disciplina TVT é específica para a Educação do Campo, com as funções de promover a interdisciplinaridade a partir dos eixos temáticos Terra Vida e Trabalho, resgatar os costumes e folclores locais, promover projetos interdisciplinares na escola, entre outros. Enfim, promover projetos que evidenciam os saberes do campo e sejam interdisciplinares. (SALOMÃO; SILVA, 2016, p.08).

Sendo assim, “... Precisa-se pensar no eixo de TVT como instrumento de construção e conservação de valores do campesinato, pois a disciplina busca 


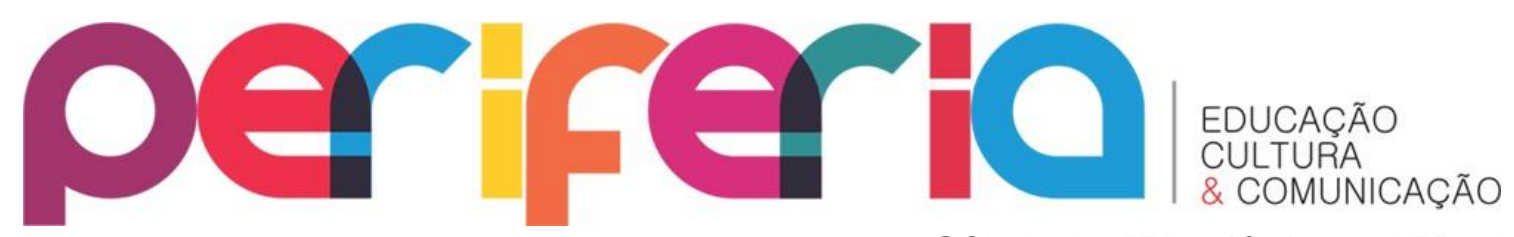

ISSN:1984-9540

DOI: $10.12957 /$ periferia.2021.55891 integrar o sujeito à sua realidade, ou seja, fortalecer os vínculos e valores do homem do campo com a terra". (LEMES; NARDOQUE, 2016, p.3).

O TVT pode ser trabalhado de diversas maneiras. Mas, consideramos que esta seria muito interessante ser trabalhada a partir de uma horta ${ }^{4}$, identificando o espaçamento entre cada plantio; estudando se aquele solo será bom para o manejo etc. Também, desenvolver projetos de reciclagem orientando o descarte correto do lixo.

Buscando assim, através dessas práticas ensinar os educandos a se identificarem com a realidade em que vivem, e incluir esses saberes adquiridos durante as aulas de TVT, no seu lote, no ambiente de sua realidade concreta, aderindo a mudanças e melhorias para a permanência do campo. As várias atividades que definem o eixo-temático dentro da unidade escolar podem se articular com a comunidade.

Segundo o professor de educação física, o mesmo que também aplica as aulas de TVT, diz que no assentamento Palmeira está em declínio, ela ainda não está alcançando a meta de como realmente deve ser trabalhada, pois essa disciplina exige muita criatividade, interesse e determinação em realizá-la, fazendo dessas aulas, as mais diversificadas e diferenciadas, chamando assim uma atenção maior dos educandos e da comunidade.

\section{Resultados da Pesquisa: Ouvindo os Sujeitos na Relação Escola-Comunidade}

Primeiramente, a pesquisa de campo foi dividida na aplicação de três entrevistas semiestruturadas, sendo elas aplicadas, aos pais dos estudantes, aos estudantes e ao diretor da escola. A pesquisa envolveu perguntas abertas, ou seja, com resultados qualitativos, e outras perguntas fechadas (quantitativas) para abordar dados estatísticos. Ambos tiveram o mesmo objetivo de interpretar as relações que envolvem a comunidade e a escola.

\section{Entrevistas semiestruturadas aplicadas aos pais}

\footnotetext{
${ }^{4}$ Lembrando que não podemos nos limitar a mesma.
} 


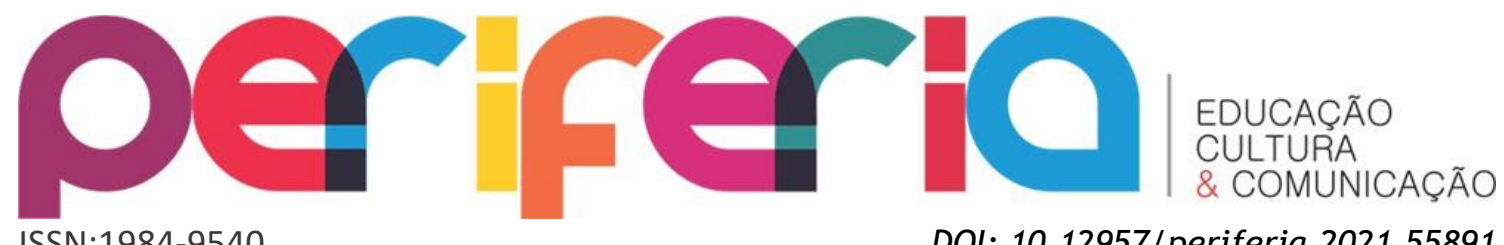

ISSN:1984-9540

DOI: 10.12957/periferia.2021.55891

Foram entrevistados cinco pais de estudantes, as entrevistas foram realizadas através de um roteiro semiestruturado contendo nove perguntas ao todo, sendo elas iguais para todos. Devido as questões serem paralelas, as perguntas número: 1; 2 e 3 será descritiva, e as perguntas 4; 5; 6 e 7, serão apresentadas através dos gráficos inseridos abaixo, e já os números 8 e 9 , serão abordadas descritivamente por quadros.

Entrevista 1: É dona de Casa, moradora há 20 anos no local, possui 1 filho e diz que a localização da escola é ótima;

Entrevista 2: Trabalha como comerciante no assentamento, morador há 11 anos no local, possui 2 filhos e diz que a localização da escola é ótima;

Entrevista 3: É dona de casa, moradora há 2 anos no local, possui 2 filhos e diz que a localização da escola é ótima;

Entrevista 4: É dona de casa, moradora há 21 anos no local, possui 1 filho e diz que a localização da escola é ótima.

Entrevista 5: Trabalha como faxineira na escola Dr. José Garcia Neto, moradora há 2 anos no local, possui 4 filhos e diz que a localização da escola é ótima.

Ao entrevistar os pais, podemos observar que no gráfico 1 que 4 entre os 5 pais entrevistados participam dessas reuniões. 0 percentual desse resultado é ótimo, vemos que nessa questão os pais são bem participativos.

Gráfico 1 - Números de famílias que costumam participar das reuniões de pais e mestres com frequência.

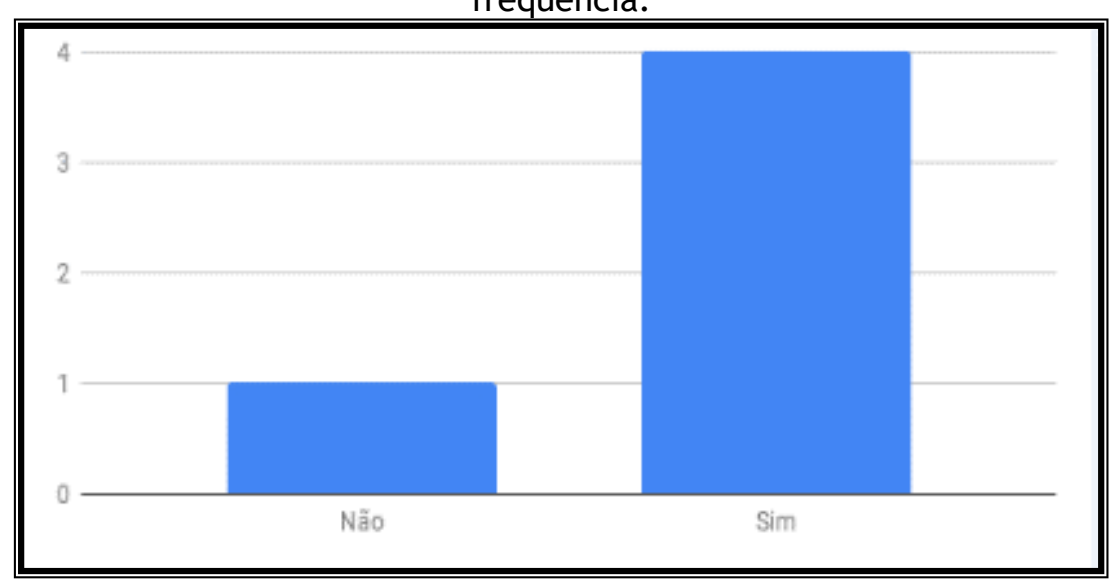

Fonte: AUTORES (2019). 


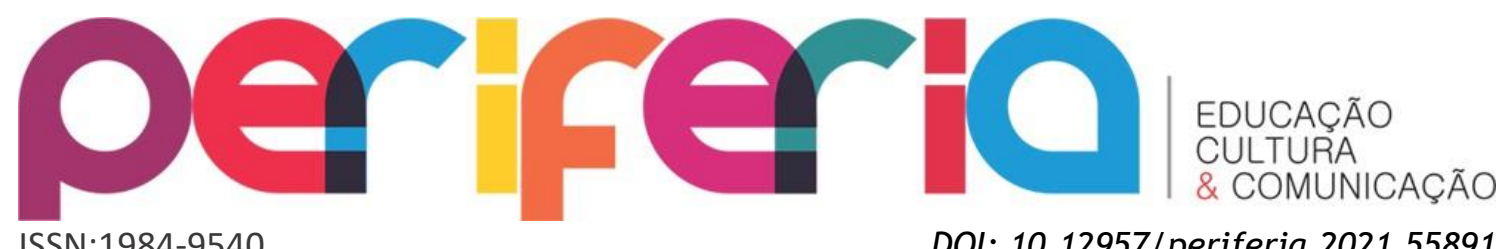

ISSN:1984-9540

DOI: $10.12957 /$ periferia.2021.55891

A partir do gráfico 2, ao serem perguntados se "A escola convida a comunidade para ajudarem em projetos a serem realizados?, temos como resposta que 3 pessoas disseram sim, que são convidados para ajudarem nos projetos que são realizados na escola, por outra parte 2 pessoas disseram que não, ou que não tem projetos. Esse resultado é relevante, mas que pode ser melhorado se a escola tiver uma interação e uma convivência maior com a comunidade, e obviamente, este resultado depende dos investimentos do poder público em atender as necessidades da escola com novos projetos.

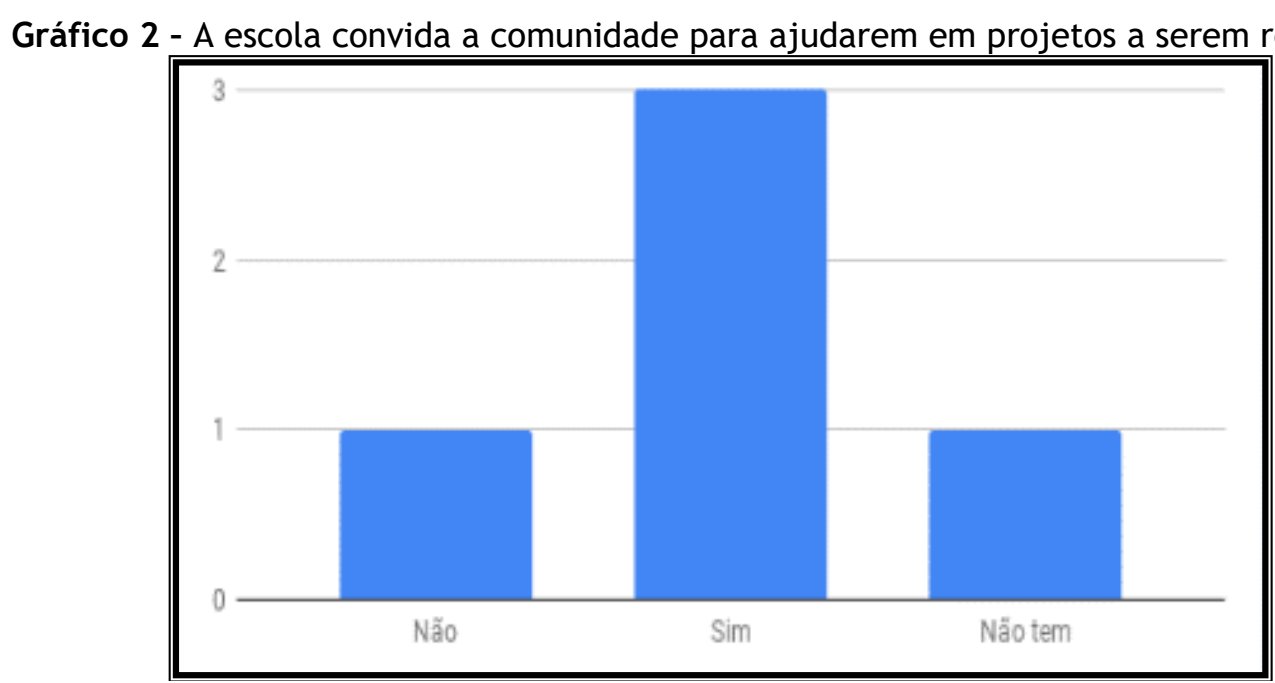

Fonte: AUTORES (2019).

No gráfico 3, sobre "o que os pais acham do ensino que é ministrado na escola", 3 deles aprovam que o ensino é muito bem aplicado aos alunos, e que seus filhos a cada dia melhoram no seu aprendizado, porém uma pessoa colocou que o ensino é regular, e outra já colocou que o ensino é ruim, pois não há professores habilitados para ministrar aulas específicas a sua formação, ficando assim outros professores a terem essa responsabilidade de aplicar tal conteúdo programático. 


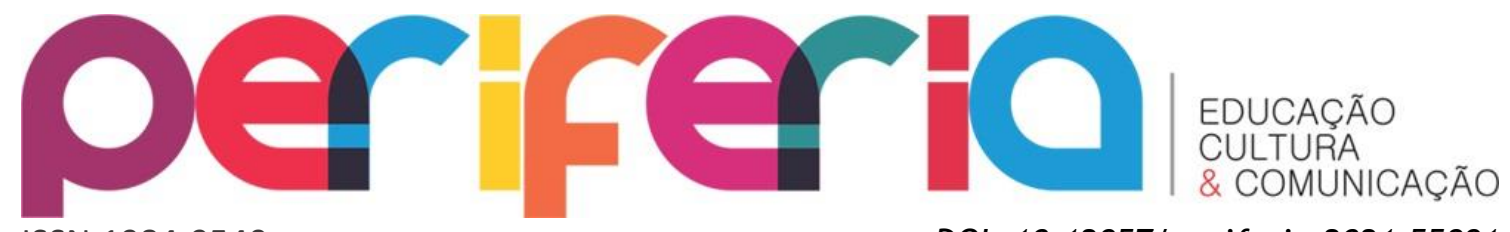

Gráfico 3 - 0 que os pais acham do ensino que é ministrado na escola

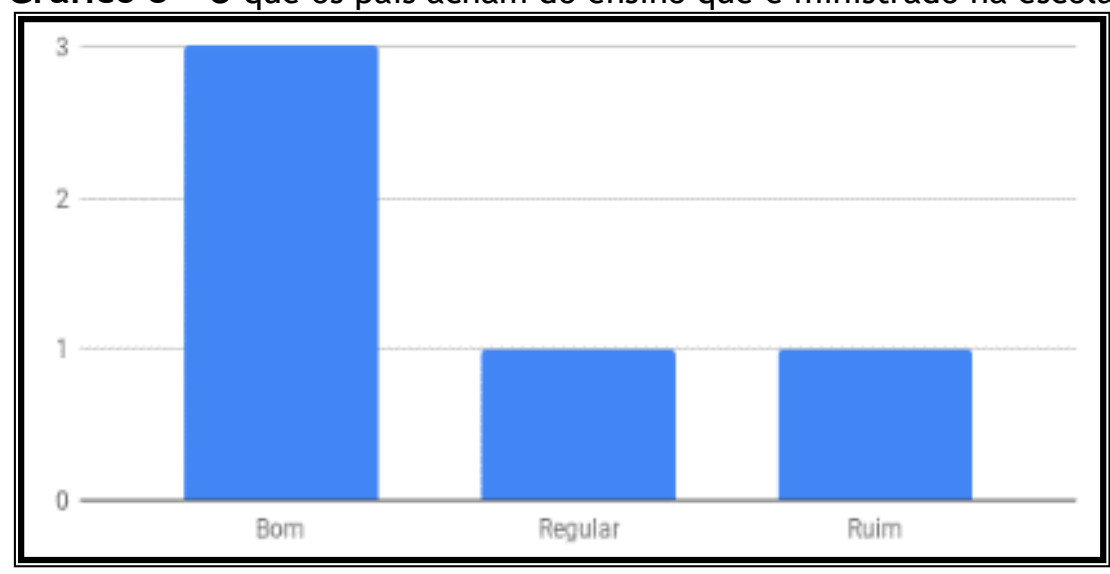

Fonte: AUTORES (2019).

No gráfico 4 (Você gostaria de participar junto com a escola dos projetos que são desenvolvidos dentro dela?), podemos ver que 3 pais disseram que gostariam muito de estar participando dos projetos que a escola oferece, e já as outras 2 pessoas disseram que não tem nenhum interesse em participar, visto que raramente acontece algum projeto na escola. Isto demonstra a necessidade de a escola divulgar mais os seus projetos com a comunidade para que todos se sintam instigados a participarem.

Gráfico 4- Você gostaria de participar junto com a escola dos projetos que são desenvolvidos dentro dela?

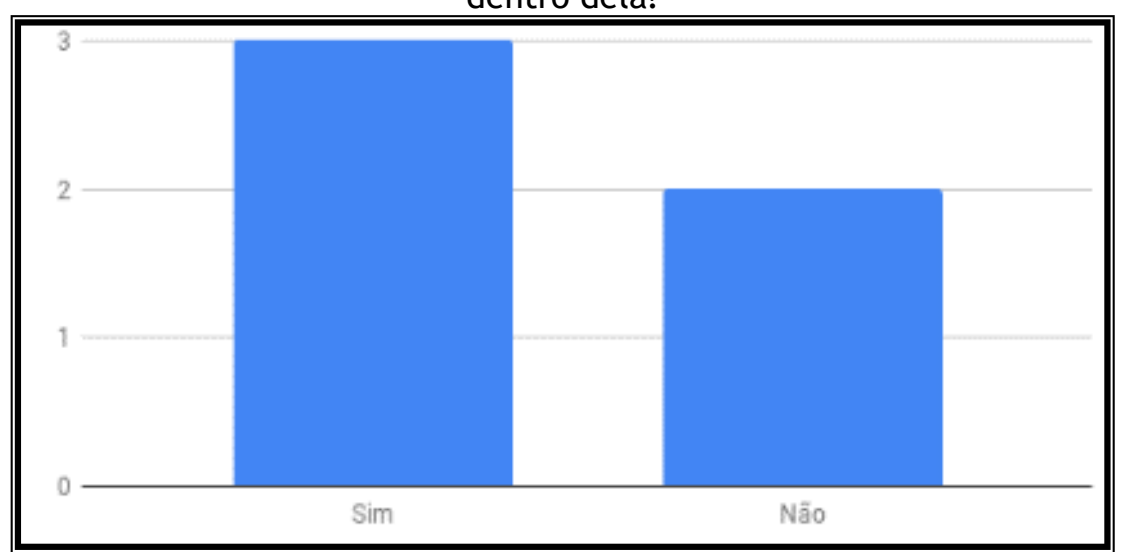

Fonte: AUTORES (2019).

Considerando que na escola existem poucos projetos que envolve a comunidade, os pais não sabem em que projetos participar, por isso, a ideia de interagir com a comunidade é muito importante. Tendo em vista que já houve 


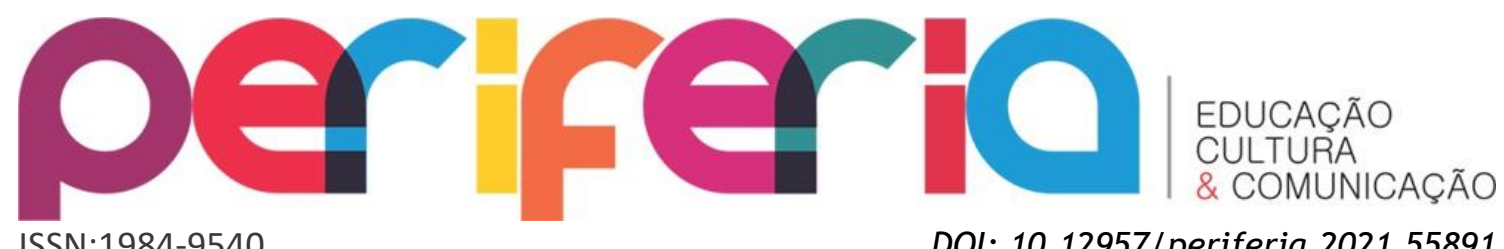

ISSN:1984-9540

DOI: $10.12957 /$ periferia.2021.55891 um projeto voltado para o meio ambiente, eles só veem este tema como opção de escolha, como mostra o quadro 1:

Quadro 1: Na sua opinião que projeto na escola você gostaria de participar?

\begin{tabular}{|c|c|}
\hline Entrevistado 1 & Sim, gostaria \\
\hline Entrevistado 2 & Algumas vezes \\
\hline Entrevistado 3 & Não sabe \\
\hline Entrevistado 4 & Projetos sobre o meio ambiente \\
\hline Entrevistado 5 & Todas, quando tem \\
\hline
\end{tabular}

Fonte: AUTORES (2019).

Com relação à questão: "Porque você considera importante ter uma escola dentro do assentamento?", no quadro 2 temos como respostas:

Quadro 2: Porque você considera importante ter uma escola dentro do assentamento?

\begin{tabular}{|c|c|}
\hline Entrevistado 1 & $\begin{array}{c}\text { Bom para os alunos aprender, pois na } \\
\text { cidade seria muito difícil. }\end{array}$ \\
\hline Entrevistado 2 & $\begin{array}{c}\text { Pra não depender de ir pra escola na } \\
\text { cidade e continuar morando no } \\
\text { assentamento. }\end{array}$ \\
\hline Entrevistado 3 & $\begin{array}{c}\text { Sim, porque pra ir na cidade é muito } \\
\text { difícil e as estradas são muito ruins } \\
\text { para o deslocamento, e a distância não } \\
\text { ajuda. }\end{array}$ \\
\hline Entrevistado 4 & $\begin{array}{c}\text { Importante, pois a escola fica perto } \\
\text { dos estudantes e dos moradores. }\end{array}$ \\
\hline Entrevistado 5 & $\begin{array}{c}\text { Para que as crianças não fiquem sem } \\
\text { estudar, pois na cidade seria inviável. }\end{array}$ \\
\hline
\end{tabular}

Fonte: AUTORES (2019).

Observando as respostas de cada entrevistado, seria muito preocupante se não houvesse essa escola inserida na comunidade, primeiro porque as crianças que moram na comunidade precisam estudar e, para isso, precisam ir à escola, ou seja, se não a tivesse ali, muitas crianças perderiam a oportunidade de estudar, haveria um índice elevado de evasão escolar. Segundo, porque sem a Escola do Campo, o trabalho pedagógico sob a perspectiva da Educação do Campo não teria mais possibilidade de ocorrer. 


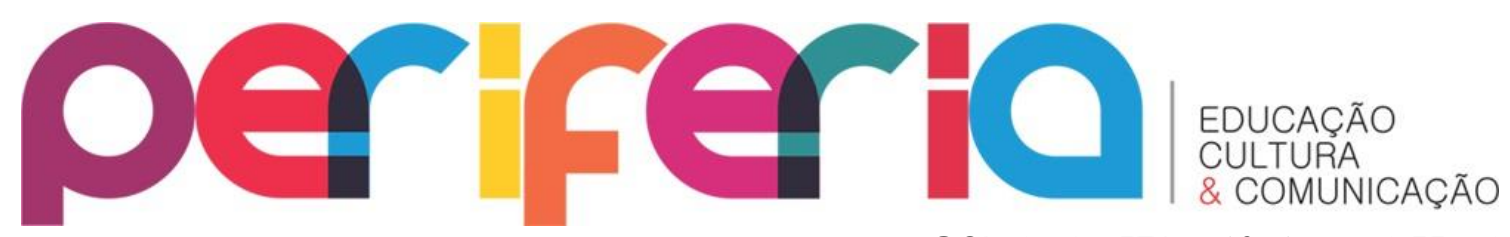

ISSN:1984-9540

DOI: $10.12957 /$ periferia.2021.55891

Neste contexto, o entrevistado 3 se posiciona dizendo que se fosse ter que se deslocar até a cidade seria muito difícil, visto que as estradas ficam em péssimas condições constantemente e os educandos teriam que levantar bem mais cedo.

Com isso tiramos as conclusões de que é muito importante que a escola continue funcionando dentro do assentamento Palmeira, caso contrário prejudicariam não só os estudantes na questão do ensino-aprendizagem, como também a comunidade, na questão de terem que se adaptar a novas mudanças, na qual, não os favorecem.

\section{Entrevista Semiestruturada aplicada aos estudantes}

A elaboração do roteiro semiestruturado ficou composto por seis perguntas ao todo, sendo elas iguais para todos os entrevistados. As perguntas são de natureza qualitativa, sem ter o objetivo de obtenção de dados numéricos.

Como nos mostra o quadro 3 , foram entrevistados estudantes do $5^{\circ}, 7^{\circ}$ e $9^{\circ}$ anos. Em suas falas os estudantes sentem muita dificuldade de aprender a matéria de Língua Portuguesa e a falta de professores não habilitados nessa disciplina na escola, é o que acarretou a essas dificuldades.

Com relação a levantarem cedo, os alunos disseram que já se sentem acostumados com o horário, pois geralmente levantam as 06 horas da manhã, pois moram perto da escola. Sobre as reuniões que são feitas, que envolvam pais e estudantes, para tratar de qualquer informação que a escola queira discutir, 4 estudantes disseram que essas reuniões ocorrem com frequência, apenas um disse que não participa. 


\section{per
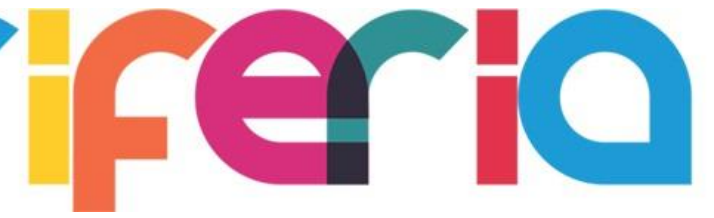 \\ EDUCAÇÃO \\ CULTURA \\ \& COMUNICAÇÃO}

ISSN:1984-9540

Quadro 3 - Formulação das perguntas e resultados da pesquisa.

\begin{tabular}{|l|l|l|l|l|}
\hline Entrevistados & $\begin{array}{l}\text { Em que } \\
\text { ano você } \\
\text { estuda? }\end{array}$ & $\begin{array}{l}\text { Qual matéria } \\
\text { você tem } \\
\text { mais } \\
\text { dificuldade } \\
\text { de aprender? }\end{array}$ & $\begin{array}{l}\text { Você acha } \\
\text { cansativo } \\
\text { levantar } \\
\text { cedo demais } \\
\text { para ir à } \\
\text { escola? }\end{array}$ & $\begin{array}{l}\text { Os professores da } \\
\text { escola realizam } \\
\text { reuniões com } \\
\text { frequência, } \\
\text { convocando pais e } \\
\text { alunos? }\end{array}$ \\
\hline Entrevista 1 & $9^{\circ}$ ano & Inglês & $\begin{array}{l}\text { Todos } \\
\text { disseram que } \\
\text { já estão } \\
\text { acostumados }\end{array}$ & Sim \\
\hline Entrevista 2 & $5^{\circ}$ ano & $\begin{array}{l}\text { Língua } \\
\text { Portuguesa }\end{array}$ & $\mathrm{X}$ & Não \\
\hline Entrevista 3 & $7^{\circ}$ ano & $\begin{array}{l}\text { Língua } \\
\text { Portuguesa }\end{array}$ & $\mathrm{X}$ & Sim \\
\hline Entrevista 4 & $9^{\circ}$ ano & $\begin{array}{l}\text { Língua } \\
\text { Portuguesa }\end{array}$ & $\mathrm{X}$ & Sim \\
\hline
\end{tabular}

Fonte: AUTORES (2019).

$\mathrm{Na}$ última questão feita, procuramos destacar os pontos positivos e negativos na visão do próprio estudante, para saber o que lhe interessava mais na escola, e o que deseja mudar.

Entrevistado 1: Positivos: jogo de futebol na aula de Educação Física, jogar vôlei e participar de alguns projetos quando tem na escola. Negativos: diz que o ensino é de má qualidade, requer mais atividades esportivas, falta de uma quadra de esportes e sala de informática.

Entrevistado 2: Positivos: mais aulas de Educação Física. Negativos: ensino de má qualidade, falta de uma quadra de esporte e área de lazer para fazer as atividades. 


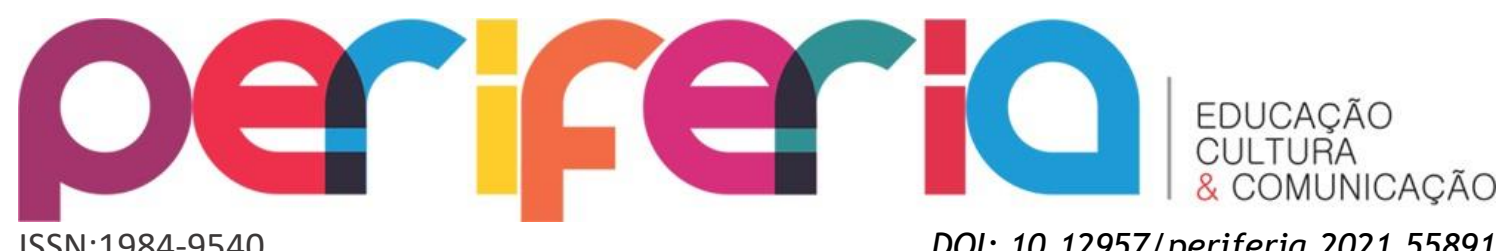

ISSN:1984-9540

DOI: 10.12957/periferia.2021.55891

Entrevistado 3: Positivos: gosta das aulas de matemática e Educação

Física. Negativos: acha que tem muitos alunos dentro de uma mesma sala, ocorrendo assim a indisciplina de alguns estudantes, pautou também no melhoramento no lanche, na falta de autoridade do professor nas aulas e da falta de uma sala de informática na escola.

Entrevistado 4: Positivos: mencionou que gosta das aulas de Educação Física e também das aulas de TVT. Negativos: reclamou de ter que estudar junto com a outra turma e que isso se torna muito difícil de prestar atenção na aula, falta de uma quadra de esportes de concreto, falta de uma sala de informática e manutenção do campo de futebol.

Entrevistado 5: Positivos: disse que não há nenhum ponto positivo, a não ser quando fazem festividades como o dos dias das crianças e a festa junina, onde fazem apresentações e convida toda a comunidade para participar. Negativos: disse que na escola falta sala de informática, falou que o lanche é servido bem pouco e reclamou do ônibus escolar que faz a linha do assentamento.

Ao analisarmos as respostas, vemos que um dos pontos positivos mais citados foi sobre as aulas de educação física, sendo assim, seria muito importante dar uma ênfase maior para essas aulas, trabalhando vários tipos de exercícios e brincadeiras, de maneira interdisciplinar, dialogando com os conteúdos de outras disciplinas e o eixo TVT. Com relação aos pontos negativos houve muitas reclamações, incluindo a falta de uma sala de informática, quadra de esportes de concreto, e também disseram que o lanche é servido muito pouco. Reclamaram também de que é muito ruim estudar em uma única sala com outra turma.

Foi de muita importância analisar os pontos negativos que os estudantes colocaram, porque só assim vemos a parte em que a escola mais precisa de ajuda, podendo assim encontrar soluções para o melhoramento desses pontos colocados em questão. 


\section{per
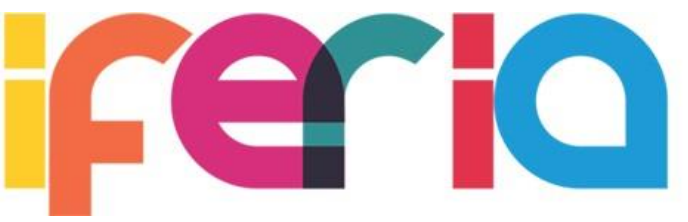

ISSN:1984-9540

\section{Entrevista Semiestruturada aplicada ao diretor da escola}

DOI: $10.12957 /$ periferia. 2021.55891

O diretor possui formação em pedagogia e gestão escolar. Mora no assentamento e vem de bicicleta para a escola. A motivação que o levou a trabalhar na escola como diretor foi justamente devido a sua especialização em gestão escolar.

Hoje em dia, a maior dificuldade encontrada na escola é a quantidade de salas multisseriadas, devido ao pequeno número de alunos e a falta de materiais pedagógicos, e assim o rendimento das aulas acabam se tornando menor mesmo com os professores sendo "habilitados" 5 .

$\mathrm{Na}$ escola, dos projetos que são desenvolvidos pelos professores, toda a comunidade participa, mas geralmente a escola costuma chamar mais os pais quando há festividades cívicas dos calendários anuais. Atualmente, a escola desenvolveu junto com a comunidade um projeto sobre o meio ambiente com a parceria da Fundação Nacional de Saúde (FUNASA).

Com relação a participação da comunidade nas reuniões, $80 \%$ dos pais frequentam, enquanto que $20 \%$ não participam. Essas reuniões servem para que os pais fiquem sabendo do aprendizado dos filhos, que segundo ele, tem se mostrado avançado. Este fato é comprovado por meio dos dados do Índice de Desenvolvimento da Educação Básica (IDEB), 2019, apontando que a nota da escola para $4^{\circ}$ e $5^{\circ}$ anos foi de $6.0^{6}$. Isto se deve aos conteúdos que são ministrados na escola, ao qual condizem com a realidade em que vivem, tentando sempre trabalhar na perspectiva da Educação do Campo no planejamento pedagógico.

\section{Discussão dos Resultados da Pesquisa}

Mediante aos dados coletados dos entrevistados, analisando suas falas de aspectos positivos e negativos, discutindo assuntos que envolvem o meio social

\footnotetext{
${ }^{5}$ Não significa, necessariamente, que em sua formação inicial tiverem em seu currículo o debate acerca da multisseriação.

${ }^{6}$ Disponível em: <http://ideb.inep.gov.br/resultado/>. Acesso em: 04 dez. 2020.
} 


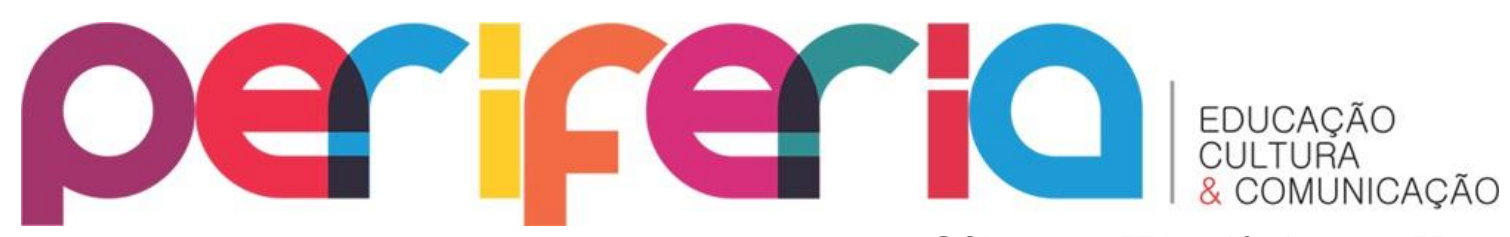

ISSN:1984-9540

DOI: $10.12957 /$ periferia.2021.55891

e as vivências por cada um deles, podemos avaliar que existe uma grande possibilidade concreta de aproximarmos essa escola da comunidade.

Por meio desta pesquisa, entendemos que é de extrema importância a permanência dessa escola no assentamento, como também a participação da comunidade é essencial no processo de ensino-aprendizagem escolar, visto que a participação dos pais na vida escolar dos filhos, é fundamental para construção de uma proposta pedagógica inovadora e emancipatória.

Apontamos, também, a questão de como estão as condições de infraestrutura da escola, ao qual foi mencionado que ainda falta muito para ser concluído como: uma biblioteca, laboratórios, quadra de esporte de concreto e uma área de lazer para fins educativos e festivos.

Neste processo de aproximação escola-comunidade, teremos que enfrentar muitos desafios. Em primeiro lugar, o interesse da escola, ou seja, que a comunidade escolar se interesse pelo planejamento e execução dos projetos. Segundo, terá que haver a disponibilidade por parte dos pais em participar com a escola, para isto estes têm que sentir parte integrante do processo. Terceiro, partilhar saberes e conhecimentos para que assim escola e comunidade possam articular formas de melhorar essa parceria para o desenvolvimento de projetos na escola.

Ao entrevistar os pais dos estudantes, podemos avaliar que, inicialmente, pareciam estar meio receosos, mas, no final, gostaram de participar. De acordo com as entrevistas, a maior dificuldade encontrada é que a escola não desenvolve projetos que chamem a atenção da comunidade para participar, ou seja, não divulgam os projetos para a comunidade. Segundo as entrevistas, houve em 2018 um projeto sobre o meio ambiente, que de maneira “informal” os pais participaram, e através disso houve, então, uma expectativa de aproximação. Foi relatado também que gostariam muito de poder estar mais próximos na abordagem dos projetos a serem desenvolvidos, participar de aulas práticas junto com os educandos e educadores.

A escola Dr. José Garcia Neto, como todo processo social, ainda se encontra em fase dialética de transformação, e uma das mudanças a ser discutida é na questão da parceria com a comunidade, pois essa aproximação 


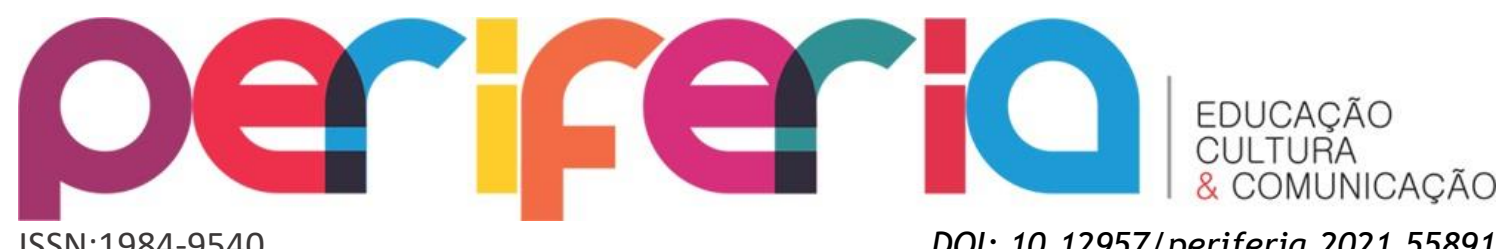

ISSN:1984-9540

DOI: $10.12957 /$ periferia.2021.55891 ainda não é tratada de maneira relevante, o que é muito preocupante, pois sem essa cooperação social, a escola pode estar correndo o risco de ser fechada.

Embora a escola ainda precise de mudanças, ela ainda se encontra dentro do campo, recebendo alunos oriundos do campo, o que é favorável para a comunidade. Vejo que se caso essa escola fechasse no assentamento, a comunidade sofreria um impacto muito drástico e geraria problemas irreversíveis, pois todos esses estudantes teriam que se deslocar do assentamento até uma cidade para estudar, e teriam então uma mudança radical nas suas vidas.

Com base nas entrevistas realizadas com os estudantes, vemos que há um descaso na adequação da infraestrutura da escola, pois os estudantes fazem uma grande reivindicação de que eles gostariam muito que na escola tivesse uma quadra de esportes coberta e de concreto e que tivesse uma área de lazer para fins educativos. Observamos também que as metodologias de ensino utilizados pelos docentes se norteiam somente no trabalho dentro sala de aula e, muitas vezes, isso acaba acarretando no desinteresse do estudante pelo conteúdo estudado, pois não enxerga a relação do mesmo com a realidade.

Sendo assim, por conta de várias desmotivações como esta, as aulas do eixo temático TVT se fazem muito importantes no processo ensinoaprendizagem da Escola do Campo, pois sugere que o educador ensine seus conteúdos através da prática, incitando no desenvolvimento do aluno em contato com a terra, o ar, o solo, a água, enfim, com a sua realidade vivida no campo. Porém, essas aulas foram poucas vezes mencionadas nas entrevistas, e isso se torna um caso a ser colocado em questão, levando em consideração a importância que tem a ajuda da comunidade no desenvolvimento de projetos que se baseia na disciplina do TVT.

Entendemos que a escola possui um espaço favorável para desenvolver tais projetos, mas para que isso se desenvolva é preciso que se mobilize em chamar todos os moradores, incluindo, alunos, professores e funcionários que trabalham na escola. E, justamente, através dessas práticas, pressionar o governo a se sensibilizar pelo esforço que a escola junto com a comunidade 


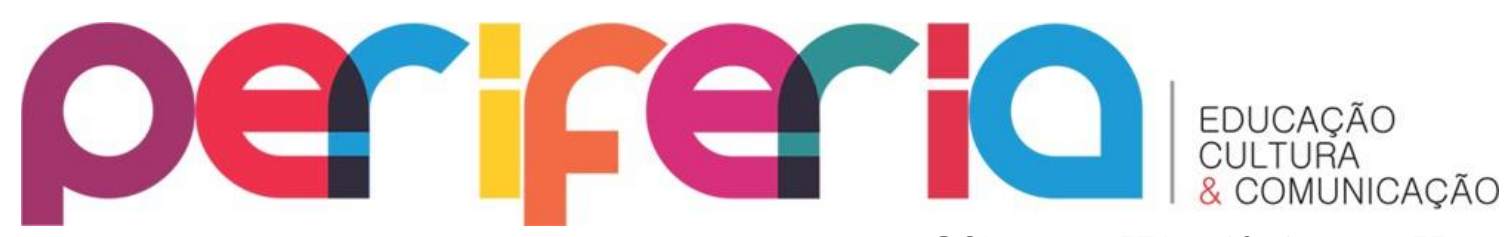

ISSN:1984-9540

DOI: 10.12957/periferia.2021.55891

está fazendo, e ajudar a reestruturar o projeto, ou seja, a formaliza-lo diante dos aspectos educacionais do campo.

O diretor da escola, Sr. Francisco dos Santos, só nos confirmou o que a comunidade relata, por isso, ainda é necessária uma maior aproximação escolacomunidade, superando os obstáculos que dificultam a realização de projetos que chamem a comunidade a participar.

Segundo o diretor, nos dias de festividades cívicas, feriados do calendário anual, a escola realiza atividades, o que faz a comunidade prestigiar o momento juntos com a escola. Isso já se torna um sinal de que não é impossível de unirmos escola-comunidade para a disponibilização em ajuda-la, e de praticar uma ação em defesa da mesma.

Acreditamos que essa aproximação aconteça aos poucos, norteamos neste trabalho, primeiramente, algumas possibilidades. Observamos os avanços e desafios de como está ocorrendo a relação escola-comunidade, e apontamos propostas para que haja o melhoramento dos projetos que estabeleça a relação escola-comunidade.

\section{Considerações Finais}

Neste trabalho, buscamos refletir sobre a importância da escola Municipal Dr. José Garcia Netto e de como funciona a relação entre a escola e a comunidade do assentamento Palmeira.

A princípio tivemos que elaborar toda a pesquisa de campo através de questionários, ao qual foram desenvolvidos e aplicados para a comunidade em si, e em seguida já com os dados em mãos começamos a parte descritiva. Analisamos na caminhada da pesquisa vários autores, que entendiam do que é realmente uma Educação do Campo, procuramos em artigos, revistas e entre outros meios, algo que estivesse relacionado com objetivo da pesquisa.

Logo em seguida, buscamos trazer a parte histórica da escola, o momento de mudanças de um assentamento para o outro, a permanência da escola no assentamento Palmeira, as lutas e dificuldades enfrentadas ao longo da história. Com isso, partimos então de como a escola se relaciona com a 


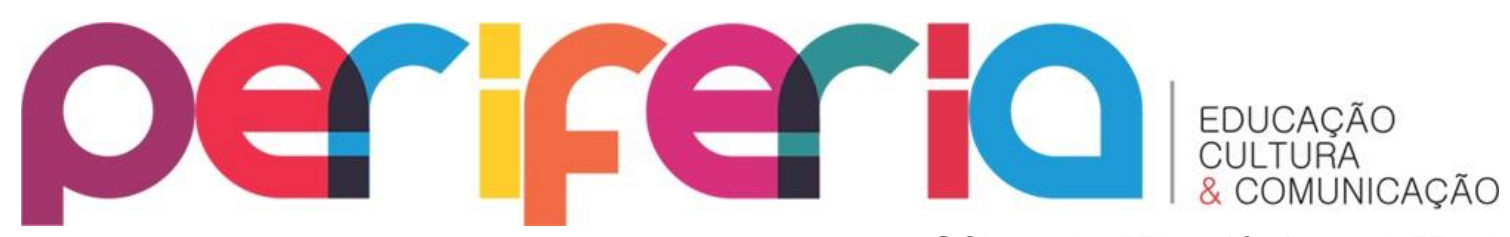

ISSN:1984-9540

DOI: 10.12957/periferia.2021.55891 comunidade, buscando entender as formas de interação, e foi onde a pesquisa de campo nos ajudou muito a sanar essas dúvidas.

Por conseguinte, essa relação entre a escola e a comunidade ainda se encontra em construção. É preciso não só ter o projeto, ou a escola se disponibilizar de forma geral, mas sim construir a interação, convivência, partilhas de conhecimentos, muita disposição e força de vontade de ambos os lados, para que possam estar mais próximos e solícitos.

\section{REFERÊNCIAS}

ARROYO, Miguel Gonzales; FERNANDES, Bernardo Mançano. A educação básica e o movimento social no campo. Brasília/DF: Ed: Zenaide, 1999. V. 02.

CALDART, Roseli Salete. Elementos para construção de projeto político pedagógico da Educação do Campo. Revista: Trabalho Necessário, n. 02, 2004.

CALDART, Roseli Salete et alii. Dicionário da educação do campo. Rio de Janeiro: Escola Politécnica de Saúde Joaquim Venâncio; São Paulo: Expressão Popular, 2012.

CAMACHO, Rodrigo Simão. A Educação do Campo e o modo de vida dos educandos - camponeses. Revista Eletrônica de culturas e educação. Caderno temático: Cultura e Educação do Campo, n. 03, nov. 2011.

CAMACHO, Rodrigo Simão; FERNANDES, Bernardo Mançano. Crítica a crítica ao paradigma da educação do campo. Práxis Educacional (Online), n. 26, v.13, p.49 - 73, 2017.

CAMACHO, Rodrigo Simão. O paradigma originário da educação do campo e a disputa de territórios materiais/imateriais com o agronegócio. Revista NERA (UNESP), v.22, n. 50, p.64 - 90, 2019.

CELI, Nelza Zülke Taffarel; CLÁUDIO, de Lira Santos Júnior; MICHELI Ortega Escobar. Cadernos didáticos sobre educação no campo. Salvador/BA, Ed: Salvador, 2010.

DEISTER, Jaqueline. Brasil de Fato, Rio de Janeiro, 2018. Disponível em: <https://www.brasildefato.com.br>. Acesso em: 26 jan. 2019.

FERNANDES, Bernardo Mançano. Os campos da pesquisa em Educação do Campo: espaço e território como categorias essenciais. In: MOLINA, Mônica 


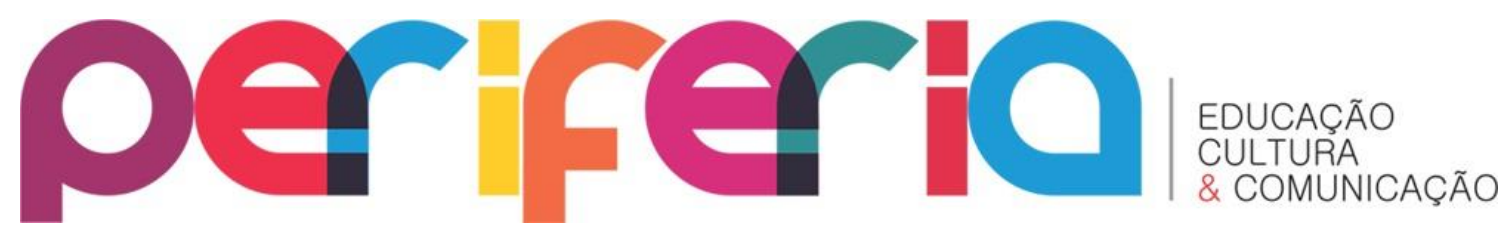

ISSN:1984-9540

DOI: $10.12957 /$ periferia.2021.55891

Castagna (Org). Educação do Campo e Pesquisa: questões para reflexão.

Brasília: Ministério do Desenvolvimento Agrário, 2006. p. 27-40.

GARCIA, Alex Barbosa. A história da luta pela terra do Assentamento Palmeira e a conquista da escola Dr. José Garcia Neto - Nioaque/MS. (Monografia em Licenciatura em Educação do Campo) - Programa de Apoio a Formação Superior em Licenciatura em Educação do Campo - PROCAMPO, Universidade Estadual do Oeste do Paraná - UNIOESTE, Cascavel/Paraná, 2014.

BRASIL. Instituto Nacional de Reforma Agrária - INCRA, Jardim/MS, 2019.

LEMES, Glaúcia dos Santos; NARDOQUE, Sedeval. Educadores do campo: Diversidades e desafios diante do eixo temático terra, vida e trabalho no ensino fundamental 1. Revista eletrônica da associação dos geógrafos brasileiros - Seção Três Lagoas/MS, n. 24, nov. 2016.

MACIEL, Gabriela Alves. Os impactos causados pelo fechamento da Escola Municipal Santa Rosa para a comunidade camponesa do assentamento Santa Rosa, Itaquiraí-MS. Monografia (Graduação em Licenciatura em Educação do Campo) - LEDUC-FAIND-UFGD, Dourados-MS, 2020.

MELO, Souza Danilo. A luta pela terra em Mato Grosso do Sul: o MST e o protagonismo da luta na atualidade. Revista Nera (UNESP), Presidente Prudente, v. 20, n. 39, 2017.

MOLINA, Mônica Castagna; FREITAS, Helana Célia de Abreu. Avanços e desafios na construção da educação do campo, v. 24. Revista Em Aberto, Brasília, abr. 2011.

MUNARIN, Antonio. Elementos para uma política pública de Educação do Campo. In: MOLINA, Mônica Castagna. Educação do campo e pesquisa: Questões para reflexão. Brasília/DF: Ministério do Desenvolvimento Agrário, 2006.

PARANÁ. Secretária de Estado da Educação - SED. Educação do Campo. Curitiba/PR. SED, Brasil, 2009.

SALOMÃO, Laura da Anunciação; SILVA, Sandra Procópio da. O Contexto Histórico da Escola do Campo no Distrito de Montese / Itaporã-MS. Cadernos de Agroecologia, v. 11, n. 2, jan. 2017.Disponível em: <http://revistas.abaagroecologia.org.br/index.php/cad/article/view/21772>.

SANTOS, Tayse Gonçalves dos. História e Perspectivas da Escola Municipal Dr. José Garcia Netto - Nioaque/MS. Monografia (Graduação em Licenciatura em Educação do Campo) - FAIND - UFGD, Dourados/MS, 2018. 


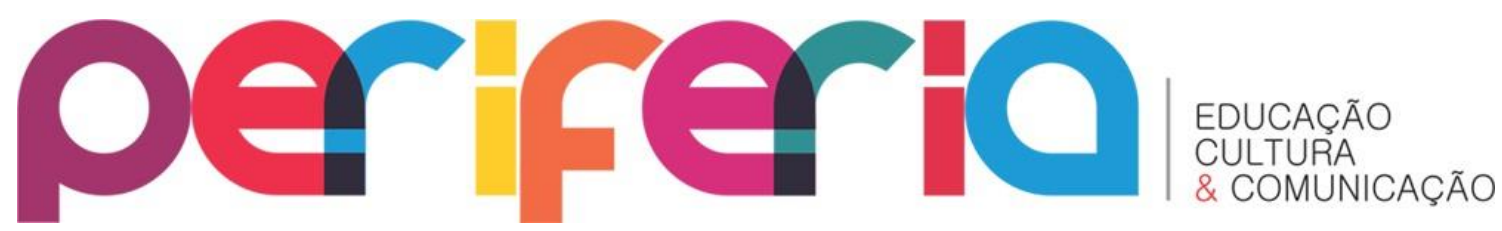

VIEIRA, Jaqueline Machado.; CAMACHO, Rodrigo Simão. A Educação do Campo na interface com a Educação Especial em nível básico e superior no município de Dourados - MS. Revista Brasileira de Educação do Campo, Tocantinópolis, v. 5, p. 1-32, 2020. 